\title{
Spatial and temporal variations in dissolved and particulate organic nitrogen in the equatorial Pacific: biological and physical influences
}

\author{
X. J. Wang ${ }^{1}$, R. Le Borgne ${ }^{2}$, R. Murtugudde ${ }^{1}$, A. J. Busalacchi ${ }^{1}$, and M. Behrenfeld ${ }^{3}$ \\ ${ }^{1}$ University of Maryland, College Park, Maryland, USA \\ ${ }^{2}$ Institut de Recherche pour le Développement, Nouméa Cédex, New Caledonia \\ ${ }^{3}$ Oregon State University, Corvallis, Oregon, USA
}

Received: 18 July 2008 - Published in Biogeosciences Discuss.: 25 August 2008

Revised: 6 November 2008 - Accepted: 25 November 2008 - Published: 11 December 2008

\begin{abstract}
To quote Libby and Wheeler (1997), "we have only a cursory knowledge of the distributions of dissolved and particulate organic nitrogen" in the equatorial Pacific. A decade later, we are still in need of spatial and temporal analyses of these organic nitrogen pools. To address this issue, we employ a basin scale physical-biogeochemical model to study the spatial and temporal variations of dissolved organic nitrogen (DON) and particulate organic nitrogen (PON). The model is able to reproduce many observed features of nitrate, ammonium, DON and PON in the central and eastern equatorial Pacific, including the asymmetries of nitrate and ammonium, and the meridional distributions of DON and PON. Modeled DON (5-8 $\mathrm{mmol} \mathrm{m}^{-3}$ ) shows small zonal and meridional variations in the mixed layer whereas modeled PON $\left(0.4-1.5 \mathrm{mmol} \mathrm{m}^{-3}\right)$ shows considerable spatial variability. While there is a moderate seasonality in both DON and PON in the mixed layer, there is a much weaker interannual variability in DON than in PON. The interannual variability in PON is largely associated with the El Niño/Southern Oscillation (ENSO) phenomenon, showing high values during cold ENSO phase but low values during warm ENSO phase. Overall, DON and PON have significant positive correlations with phytoplankton and zooplankton in the mixed layer, indicting the biological regulation on distribution of organic nitrogen. However, the relationships with phytoplankton and zooplankton are much weaker for DON ( $r=0.18-0.71)$ than for PON ( $r=0.25-0.97)$. Such a difference is ascribed to a relatively larger degree of physical control (e.g., upwelling of low-organic-N deep waters into the surface) on DON than PON.
\end{abstract}

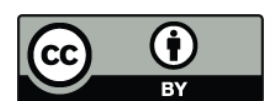

Correspondence to: X. J. Wang (wwang@essic.umd.edu)

\section{Introduction}

The central and eastern equatorial Pacific regions display persistent High-Nutrient-Low-Chlorophyll (HNLC) conditions, which are attributable to both the micro-nutrient limitations on phytoplankton growth and the grazing control on phytoplankton abundance by micro-zooplankton (Landry et al., 1997; Landry and Kirchman, 2002; Le Borgne and Landry, 2003; Wang et al., 2005a). It is believed that community growth is limited by insufficient iron in the euphotic zone (Coale et al., 1996; Martin et al., 1994; Wang et al., 2005a; Behrenfeld et al., 2006), and diatom growth also by silica Dugdale and Wilkerson, 1998; Chai et al., 2002). To date, most studies of the marine nitrogen cycle have largely focused on the distribution and behavior of nitrate in the equatorial Pacific. As Libby and Wheeler (1997) stated, "we have only a cursory knowledge of the distributions of dissolved and particulate organic nitrogen in this region," and "a comprehensive evaluation of both inorganic and organic $\mathrm{N}$-pools is important to achieve an understanding of the transport and regeneration of nitrogen in the equatorial Pacific."

While there are several field studies which have measured particulate organic nitrogen (PON) in the equatorial Pacific (Libby and Wheeler, 1997; Eppley et al., 1992; Raimbault et al., 1999; Pena et al., 1991, 1992), only two studies have reported concentrations of dissolved organic nitrogen (DON) (Raimbault et al., 1999; Libby and Wheeler, 1997). The limited data show little variations in both PON and DON concentrations below $150 \mathrm{~m}$ in the central equatorial Pacific (Raimbault et al., 1999). Overall, observations show considerable variations in the surface PON $(>0.7 \mu \mathrm{m})$ concentrations $\left(0.4-1.6 \mathrm{mmol} \mathrm{m}^{-3}\right)$ but a relatively small range of the surface DON concentration (4-9 $\mathrm{mmol} \mathrm{m}^{-3}$ ).

Published by Copernicus Publications on behalf of the European Geosciences Union. 


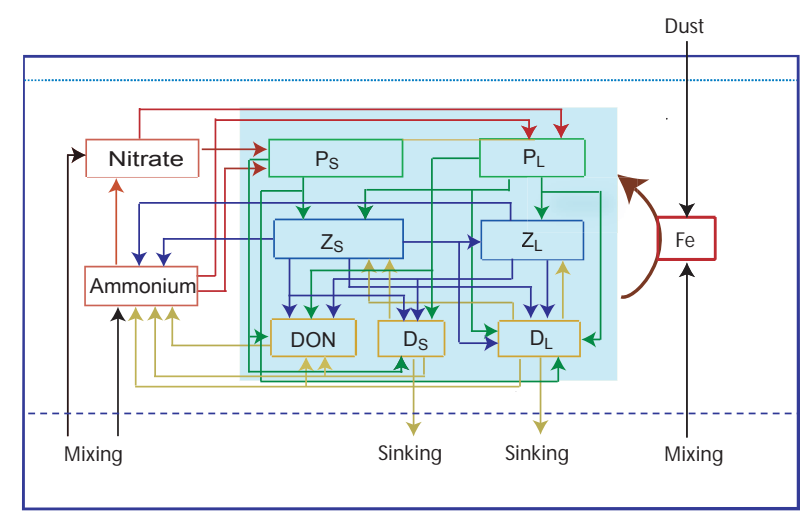

Fig. 1. Flow diagram of ecosystem model. Red, green, blue and yellow lines and arrows denote nitrogen fluxes originating from inorganic forms, phytoplankton cells, zooplankton cells, and DON and detritus, respectively. Black lines and arrows denote physical supply of nutrients.

Overall, the surface DON concentrations show relatively weak meridional variations in the central and eastern equatorial Pacific. Interestingly, there is a considerable difference (approximately $2 \mathrm{mmol} \mathrm{m}^{-3}$ ) in the surface DON concentration between the two reports with relatively higher values along $125^{\circ} \mathrm{W}$ and $140^{\circ} \mathrm{W}$ during September-November 1992 (Libby and Wheeler, 1997) than along $150^{\circ} \mathrm{W}$ during November 1994 (Raimbault et al., 1999). One would ask if such a difference is ascribed to the spatial variability (i.e., $125^{\circ} \mathrm{W}-140^{\circ} \mathrm{W}$ vs. $150^{\circ} \mathrm{W}$ ), the interannual variability (i.e., 1992 vs. 1994), or both? Previous observation and modeling studies have shown large spatial and temporal variations in physical and biogeochemical processes occurring in the equatorial Pacific (Feely et al., 2002, 2006; Chavez et al., 1999; Murtugudde et al., 1999; Wang et al., 2006a, b). However, little is known about the large scale spatial and temporal variations of DON and PON in the equatorial Pacific. Observations are limited not only in terms of spatial and temporal coverage, but also in terms of a lack of key parameters regulating the variability. Hence, modeling studies offer considerable promise not only for filling the gaps in the spatiotemporal variability, but also for enhancing our understanding of the mechanisms underlying the observed variability.

In this study, we apply a fully coupled basin-scale physical-biogeochemical model that is developed for the equatorial Pacific (Christian et al., 2002; Wang et al., 2006a). The model has shown the ability of simulating the ecosystem dynamic, and spatial and temporal variations in biogeochemical fields (e.g., chlorophyll, primary productivity, new production, sea surface $\mathrm{pCO}_{2}$ and ocean-atmosphere $\mathrm{CO}_{2}$ fluxes) (Wang et al., 2005a, 2006a, b). The objective of this study is to investigate the spatial and temporal variability of DON and PON and biological vs. physical influences. Our approach includes model validations of the main nitrogen components, and analyses of relationships of DON and PON with various physical and biogeochemical parameters.
Table 1. Southern Oscillation Index (SOI), PON and DON concentrations $\left(\mathrm{mmol} \mathrm{m}^{-3}\right)$ in the area of $140^{\circ} \mathrm{W}-125^{\circ} \mathrm{W}, 8^{\circ} \mathrm{N}-8^{\circ} \mathrm{S}$, and the least significant difference (LSD) among three periods.

\begin{tabular}{llrccc}
\hline Year & Month & SOI & Data PON & Model PON & Model DON \\
\hline 2005 & September & 0.4 & 0.73 & 1.16 & 6.62 \\
2006 & January & 1.8 & 0.67 & 1.12 & 6.72 \\
2006 & September & -0.7 & 0.61 & 1.06 & 6.57 \\
LSD (P=0.05) & & & 0.05 & 0.02 & 0.02 \\
\hline
\end{tabular}

\section{Materials and methods}

\subsection{Ocean physical-biogeochemical model}

The ocean general circulation model (OGCM) is based on a primitive equation, $\sigma$-coordinate model that is coupled to an advective atmospheric mixed layer model (Gent and Cane, 1989; Murtugudde et al., 1996). The model has 20 vertical layers with variable thickness. The first layer, the mixed layer, is determined by surface turbulent kinetic energy generation, dynamic instability mixing, and convective mixing to remove static instabilities (Chen et al., 1994). The model is set up for the Pacific domain between $30^{\circ} \mathrm{S}-30^{\circ} \mathrm{N}$, with zonal resolution of $1^{\circ}$ longitude, and stretched meridionally $0.3^{\circ}$ within $5^{\circ} \mathrm{S}-5^{\circ} \mathrm{N}$ to $0.5^{\circ}$ in the off-equatorial regions $\left(5^{\circ}-15^{\circ}\right)$ and $1^{\circ}$ near the southern and northern boundaries.

The model is forced by solar radiation, cloudiness, surface wind stress, and precipitation. The air temperature and humidity are computed by the atmospheric mixed layer model. The solar radiation, precipitation, and cloudiness are climatologic monthly means. The surface wind stresses are 6day means from the NCEP reanalysis (Kalnay et al., 1996). Wind-speeds are computed from wind-stresses, resulting in interannual wind forcing and latent and sensible heat fluxes which are the most important surface forcings at interannual time-scales in the equatorial Pacific. Initial conditions are taken from a climatological run, which has been spun up for 30 years with initial conditions from the WOA98 atlas (http://www.nodc.noaa.gov/OC5/data_woa.html). We then perform an interannual run starting from 1948, and use model outputs from the period of 1990-2007 for our analyses.

The biogeochemical model, modified from that of Wang et al. (2006a), consists of three nutrients: nitrate, ammonium, and dissolved iron, and seven biological pools: small (S) and large (L) sizes of phytoplankton $\left(\mathrm{P}_{S}\right.$ and $\left.\mathrm{P}_{L}\right)$, zooplankton $\left(\mathrm{Z}_{S}\right.$ and $\left.\mathrm{Z}_{L}\right)$ and detritus $\left(\mathrm{D}_{S}\right.$ and $\left.\mathrm{D}_{L}\right)$, and dissolved organic nitrogen (DON) (Fig. 1). All biogeochemical variables are computed in a similar manner to physical fields for all 20 layers without restoration. The biological source/sink term is calculated by the equations given in Appendix A. Model biological parameters are given in Appendix B. Modeled total inorganic nitroegen (TIN) is a sum of nitrate and ammonium 
Table 2. Correlations (r) of the mixed layer DON and PON with Z20, ferricline, mixed layer iron concentration, phytoplankton biomass (Phyto), and zooplankton biomass (Zoo) using monthly averages for the period of 1990-2007.

\begin{tabular}{lrrrrr}
\hline Region & Z20 & Ferricline & Iron & Phyto & Zoo \\
\hline NCP $\left(5^{\circ} \mathrm{N}-0^{\circ}, 150^{\circ} \mathrm{W}\right)$ & -0.03 & -0.11 & 0.00 & $0.50^{* * *}$ & $0.56^{* * * *}$ \\
$\mathrm{NEP}\left(5^{\circ} \mathrm{N}-0^{\circ}, 110^{\circ} \mathrm{W}\right)$ & 0.10 & -0.06 & -0.01 & $0.40^{* * *}$ & $0.18^{*}$ \\
$\mathrm{SCP}\left(0^{\circ}-5^{\circ} \mathrm{S}, 150^{\circ} \mathrm{W}\right)$ & $0.15^{*}$ & 0.14 & $0.20^{* *}$ & $0.48^{* * *}$ & $0.60^{* * *}$ \\
$\mathrm{SEP}\left(0^{\circ}-5^{\circ} \mathrm{S}, 110^{\circ} \mathrm{W}\right)$ & -0.01 & $0.18^{*}$ & $0.28^{* *}$ & $0.66^{* * *}$ & $0.71^{* * * *}$ \\
\hline $\mathrm{PON}-\mathrm{NCP}\left(5^{\circ} \mathrm{N}-0^{\circ}, 150^{\circ} \mathrm{W}\right)$ & $-0.29^{* *}$ & $-0.34^{* * *}$ & $0.75^{* * *}$ & $0.66^{* * *}$ & $0.97^{* * *}$ \\
$\mathrm{NEP}\left(5^{\circ} \mathrm{N}-0^{\circ}, 110^{\circ} \mathrm{W}\right)$ & $-0.38^{* * *}$ & $-0.32^{* * *}$ & $0.69^{* * *}$ & $0.25^{* *}$ & $0.97 * * *$ \\
$\mathrm{SCP}\left(0^{\circ}-5^{\circ} \mathrm{S}, 150^{\circ} \mathrm{W}\right)$ & 0.03 & -0.01 & $0.81^{* * *}$ & $0.74^{* * *}$ & $0.97^{* * * *}$ \\
$\mathrm{SEP}\left(0^{\circ}-5^{\circ} \mathrm{S}, 110^{\circ} \mathrm{W}\right)$ & $-0.26^{* *}$ & $-0.39^{* * *}$ & $0.72^{* * *}$ & $0.74^{* * *}$ & $0.92^{* * *}$ \\
\hline
\end{tabular}

Values shown are Pearson correlation coefficients. Significant correlations are marked with one $(\mathrm{p}<0.05)$, two $(\mathrm{p}<0.01)$ and three $(\mathrm{p}<0.001)$ asterisks.

whereas modeled PON is estimated as a sum of phytoplankton, small zooplankton, and detritus: $\mathrm{PON}=\mathrm{P}_{S}+\mathrm{P}_{L}+\mathrm{Z}_{S}+$ $\mathrm{D}_{S}+\mathrm{D}_{L}$.

\subsection{In situ PON data}

As part of the Equatorial Box Project (http://web.science. oregonstate.edu/ocean.productivity/box.php), surface PON measurements were conducted during three Tropical Atmosphere Ocean (TAO) cruises in September 2005, January 2006, and September 2006. Water samples were collected at $3 \mathrm{~m}$ from the flow-through seawater system, and filtered through pre-combusted Whatman GF/F filters. Filters were individually sealed in aluminum foil sleeves and placed in liquid Nitrogen for the remainder of the cruise and transport back to the lab. Prior to laboratory analysis, filters were dried at $50^{\circ} \mathrm{C}$ then packed into Nickel sleeves which had been precombusted in a muffle furnace at $900^{\circ} \mathrm{C}$ for one hour. The filters were analyzed for nitrogen contents using a carbonhydrogen-nitrogen $(\mathrm{CHN})$ elemental analyzer (Exeter Analytical Inc. Model 440). Technique details regarding CHN sampling and measurements can be found in Behrenfeld and Boss (2006). PON data can be accessed at http://web.science. oregonstate.edu/ocean.productivity/box.data.php.

\subsection{Other in situ data}

Previous field studies reported in situ PON concentration for the surface water along $140^{\circ} \mathrm{W}, 125^{\circ} \mathrm{W}$, and $110^{\circ} \mathrm{W}$ during September-November 1992 (Libby and Wheeler, 1997), and for the vertical distributions along $150^{\circ} \mathrm{W}$ during November 1994 (Raimbault et al., 1999). From the early study (Libby and Wheeler, 1997), averaged surface PON concentration showed a range of $0.9-1.9 \mathrm{mmol} \mathrm{m}^{-3}$ for $>0.2 \mu \mathrm{m}$ particles, and $0.4-1.6 \mathrm{mmol} \mathrm{m}^{-3}$ for $>0.7 \mu \mathrm{m}$ particles. For the late study (Raimbault et al., 1999), PON concentration ranged from $0.2 \mathrm{mmol} \mathrm{m}^{-3}$ below $100 \mathrm{~m}$ to $0.4-0.6 \mathrm{mmol} \mathrm{m}^{-3}$ near the surface along $150^{\circ} \mathrm{W}$, which was much lower than the concentrations of $>0.7 \mu \mathrm{m}$ PON measured by Libby and Wheeler (1997). In this study, we use the mean surface concentrations of $>0.7 \mu \mathrm{m}$ PON (Table 1 in Libby and Wheeler, 1997). We obtain the surface DON concentrations by subtracting PON from total organic nitrogen (TON) in their Table 2. We also use their data of nitrate and nitrite to estimate TIN.

\section{Results}

\subsection{Model-data comparisons}

Figure 2 presents the comparisons of surface TON, TIN, DON and PON between the model and the observations during the period of September-November, 1992. Overall, modeled surface TON and TIN show good agreement with observations in the eastern equatorial Pacific (Libby and Wheeler, 1997). For example, model simulations capture the observed meridional variations of surface TIN, which is the highest on the equator, and relatively higher to the south than to the north. While the model simulates reasonable surface TON concentrations, the model underestimates the surface DON concentrations especially north of the equator along $140^{\circ} \mathrm{W}$ and $125^{\circ} \mathrm{W}$. Modeled PON concentration is slightly higher than the observed on the equator. Interestingly, the magnitude and meridional variation of PON $\left(\sim 0.5 \mathrm{mmol} \mathrm{N} \mathrm{m}^{-3}\right.$ off the equator and $\sim 1 \mathrm{mmol} \mathrm{N} \mathrm{m}^{-3}$ on the equator) from the model are similar to those measured at $135^{\circ} \mathrm{W}$ during April 1988 (Pena et al., 1991).

Hydrological and biological data were collected along $150^{\circ} \mathrm{W}$ during November 1994 in the equatorial Pacific (Raimbault et al., 1999), which allows us to further validate the biogeochemical model. Here, we present model simulations of nitrate, ammonium, DON and PON for the same period, to compare with those presented in their Figs. 4 and 

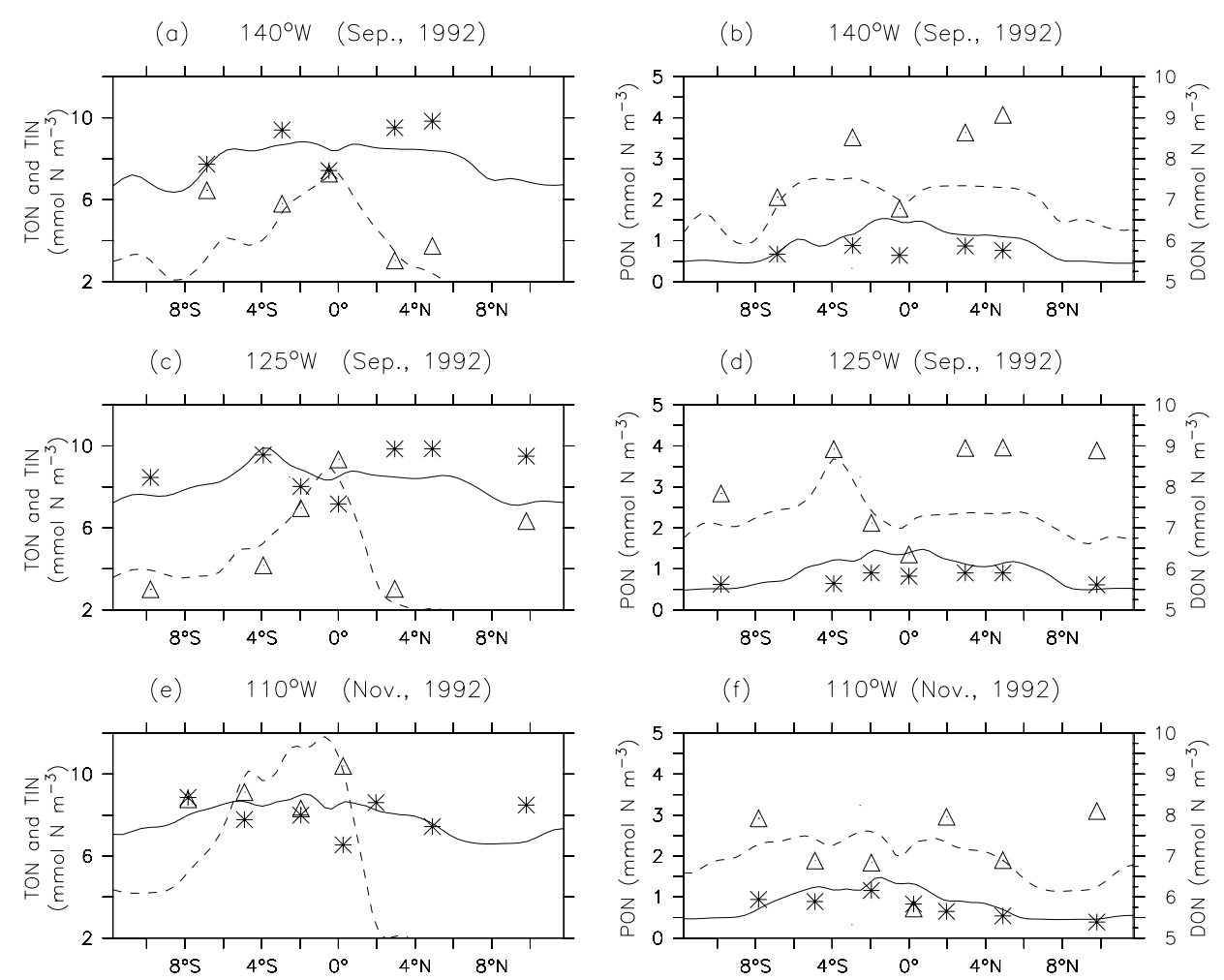

Fig. 2. Modeled (lines) versus observed (symbols) surface $(0-40 \mathrm{~m})$ concentrations of TON, TIN, PON and DON along (a) and (b) $140^{\circ} \mathrm{W}$, (c) and (d) $125^{\circ} \mathrm{W}$, and (e) and (f) $110^{\circ} \mathrm{W}$. Left column: solid lines and stars denote TON, and dashed lines and triangles TIN. Right column: solid lines and stars denote PON, and dashed lines and triangles DON. Data are from (Libby and Wheeler, 1997). For both model and data, TON = PON + DON; for Model, TIN = nitrate + ammonium; for data, TIN = nitrate + nitrite .

5. Our model does not have other inorganic nitrogen pools such as nitrite and urea so we expect that modeled nitrate concentration may be slightly higher than in situ nitrate concentration. Model simulations capture some of the observed features, as documented by Raimbault et al. (1999), for nitrate and ammonium (Fig. 3), including the deep ammonium maximum at $\sim 100 \mathrm{~m}$, and the asymmetric features of nitrate and ammonium. Modeled DON and PON show relatively uniform distributions in the upper $100 \mathrm{~m}$, which is similar to the observations. For instance, modeled surface DON variations $\left(4.5-7 \mathrm{mmol} \mathrm{m}^{-3}\right)$ are similar to the observed values $\left(5-6.5 \mathrm{mmol} \mathrm{m}^{-3}\right)$. However, modeled surface PON variations $\left(0.3-1.2 \mathrm{mmol} \mathrm{m}^{-3}\right)$ are considerably larger than the observed $\left(0.3-0.6 \mathrm{mmol} \mathrm{m}^{-3}\right)$, which may be partly due to the inclusion of zooplankton (see discussion in the Sect. 4.1).

Recent observations show that the near surface $(3 \mathrm{~m})$ PON concentrations range from 0.5 to $1 \mathrm{mmol} \mathrm{m}^{-3}$ with slightly higher values near the equator along $125^{\circ} \mathrm{W}-140^{\circ} \mathrm{W}$ (Fig. 4). These recent data also show considerable short-term variations (e.g., from 0.55 to $0.74 \mathrm{mmol} \mathrm{m}^{-3}$ at $140^{\circ} \mathrm{W}, 8^{\circ} \mathrm{S}$ in 9 September 2005), suggesting the possibility of a diel cycle. It is not meaningful to inter-compare the model and data at shorter than weekly time-scales since the model is forced by weekly mean surface conditions. Here, we show monthly mean concentrations of mixed layer PON from the model. The modeled PON concentrations $\left(0.8-1.2 \mathrm{mmol} \mathrm{m}^{-3}\right)$ in the mixed layer are systematically higher than the measured PON concentration near the surface. We will further discuss the issues of model-data and data-data comparisons in the Discussion section.

\subsection{Spatial distributions and seasonal variability}

Figure 5 shows the climatology (1990-2007) of the mixed layer and vertical distributions of DON and PON from the model. Model simulation shows a narrow range for the mixed layer DON $\left(5-7 \mathrm{mmol} \mathrm{m}^{-3}\right)$. Zonal and meridional variations in the mixed layer DON are small (varing by less than a factor of two), which is different to most of the other biogeochemical parameters (varying by a factor of 3 to 10) such as phytoplankton and zooplankton biomass, primary productivity or new production (e.g., Wang et al., 2006a). Model simulations show little change in the mixed layer DON concentrations from $150^{\circ} \mathrm{W}$ to $140^{\circ} \mathrm{W}-125^{\circ} \mathrm{W}$, which rules out the possible responsibility of spatial variability for the reported DON differences between along $150^{\circ} \mathrm{W}$ during November 1994 (Raimbault et al., 1999) and along $125^{\circ} \mathrm{W}$ and $140^{\circ} \mathrm{W}$ during September-November 1992 (Libby and Wheeler, 1997). 

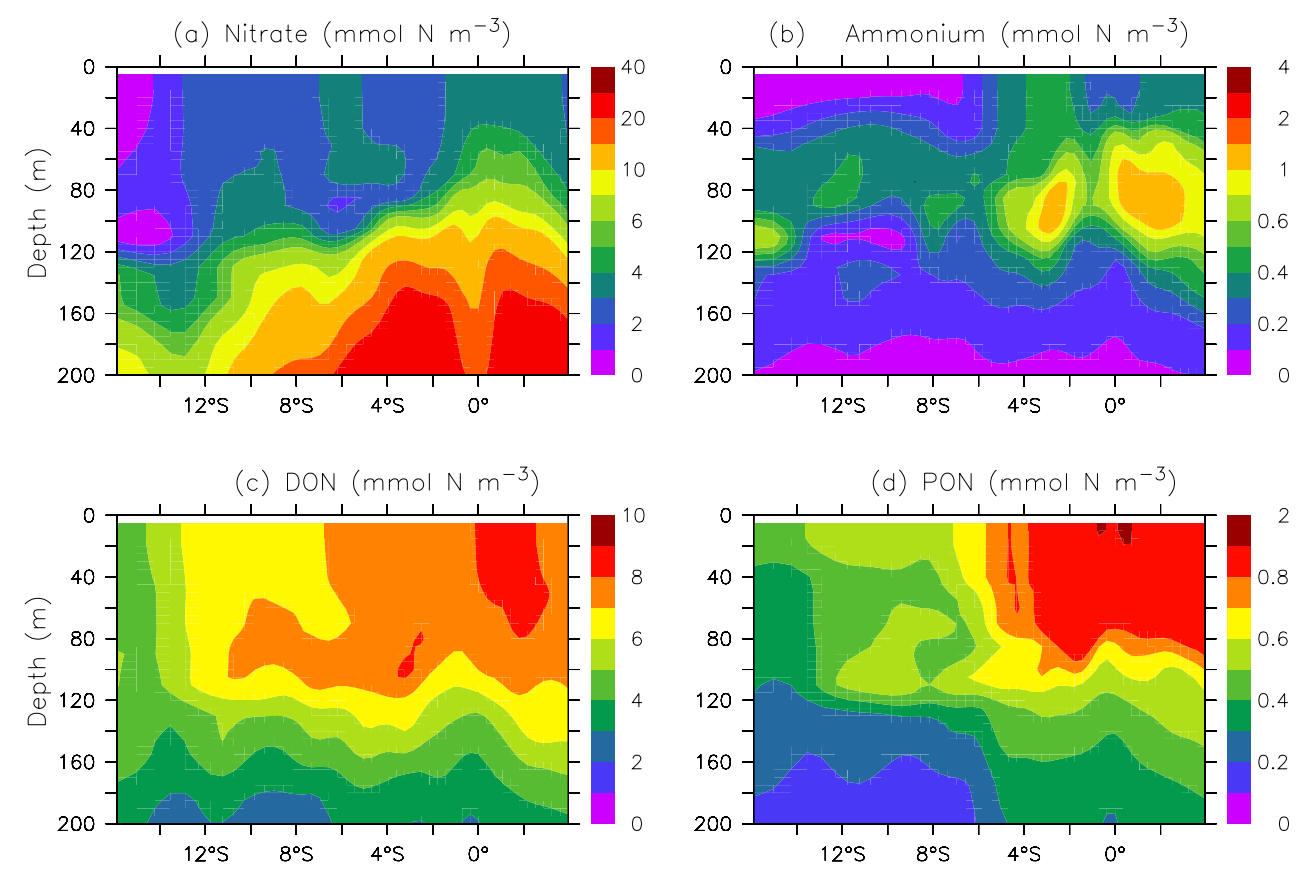

Fig. 3. Modeled contour plots of (a) nitrate, (b) ammonium, (c) DON, and (d) PON along 150 W in November 1994.

Modeled surface PON shows considerable spatial variability with the highest concentrations revealed along the equator, which is similar to those of phytoplankton and zooplankton biomass, primary productivity and new production (e.g., Wang et al., 2006a). Similar meridional variations have been found in the in situ surface PON in 1988 (Pena et al., 1991) and 2005-2006 (Fig. 4), and in the satellite-derived surface particulate organic carbon (POC) in the equatorial Pacific (Gardner et al., 2006). The subsurface DON shows relatively higher concentrations in the central equatorial Pacific than in the eastern equatorial Pacific. However, the subsurface PON shows little zonal variability.

The equatorial Pacific undergoes significant seasonal changes in physical processes: the warm season (MarchMay) in association with large solar warming and weak wind mixing (Cronin and Kessler, 2002), and the upwelling season with strong winds in boreal fall. Our previous studies have shown seasonal patterns and asymmetric features in physical and biogeochemical fields. This study shows marked differences in the seasonal variations of the mixed layer DON and PON between the north band $\left(5^{\circ} \mathrm{N}-0^{\circ}\right)$ and south band $\left(0^{\circ}-5^{\circ} \mathrm{S}\right)$ (Fig. 6). In the north band, modeled iron, DON and PON concentrations show considerable seasonal variations in the mixed layer $\left(\sim 10 \mathrm{nmol} \mathrm{m}^{-3}, \sim 1 \mathrm{mmol} \mathrm{m}^{-3}\right.$ and $>0.3 \mathrm{mmol} \mathrm{m}^{-3}$ in amplitude, respectively) with the highest values in boreal spring in the central equatorial Pacific. In contrast, there is a strong seasonality in the mixed layer iron concentration $\left(>20 \mathrm{nmol} \mathrm{m}^{-3}\right)$ with the highest values in boreal summer/fall in the south band of the eastern equatorial Pacific. While high concentrations of DON and PON coincide with high iron concentrations, the seasonality is relatively weak in the mixed layer DON $\left(\sim 1 \mathrm{mmol} \mathrm{m}^{-3}\right)$ and PON $\left(<0.3 \mathrm{mmol} \mathrm{m}^{-3}\right)$ given the strong seasonality in the mixed layer iron concentration.

Figure 7 presents the simulated mixed layer depth (MLD), the $20^{\circ} \mathrm{C}$ isotherm depth (Z20), and DON profiles along $150^{\circ} \mathrm{W}$ and $110^{\circ} \mathrm{W}$ during boreal spring (March-May) and fall (September-November). Clearly, there are pronounced asymmetries in MLD and Z20. Asymmetric features have been found in nitrate, silicate, dissolved inorganic carbon, and sea surface $\mathrm{pCO}_{2}$ in the equatorial Pacific (Feely et al., 1997; Jiang and Chai, 2005; Murray et al., 1995; Archer et al., 1997; Dugdale et al., 2002), which may be largely associated with the asymmetries in mass exchanges between the equatorial and off-equatorial Pacific Ocean (Kug et al., 2003). However, modeled DON reveals weak to moderate asymmetric features in the upper $200 \mathrm{~m}$. Model simulations show subsurface DON maxima off the equator, which has been observed along $150^{\circ} \mathrm{W}$ (Raimbault et al., 1999). In general, DON concentrations below $120 \mathrm{~m}$ are lower on the equator than off the equator particularly in the eastern equatorial Pacific, which may reflect upwelling of low-DON waters from deep layers.

Modeled PON shows considerable asymmetries in the upper $100 \mathrm{~m}$, but weak asymmetries below $100 \mathrm{~m}$ (Fig. 8). The model reproduces some observed PON features such as a surface peak on the equator, and subsurface maxima off the equator (Pena et al., 1992). The subsurface PON maxima appear when the off-equatorial MLD is relatively shallow. Unlike DON, PON concentrations below $120 \mathrm{~m}$ are higher 
(a) September 2005

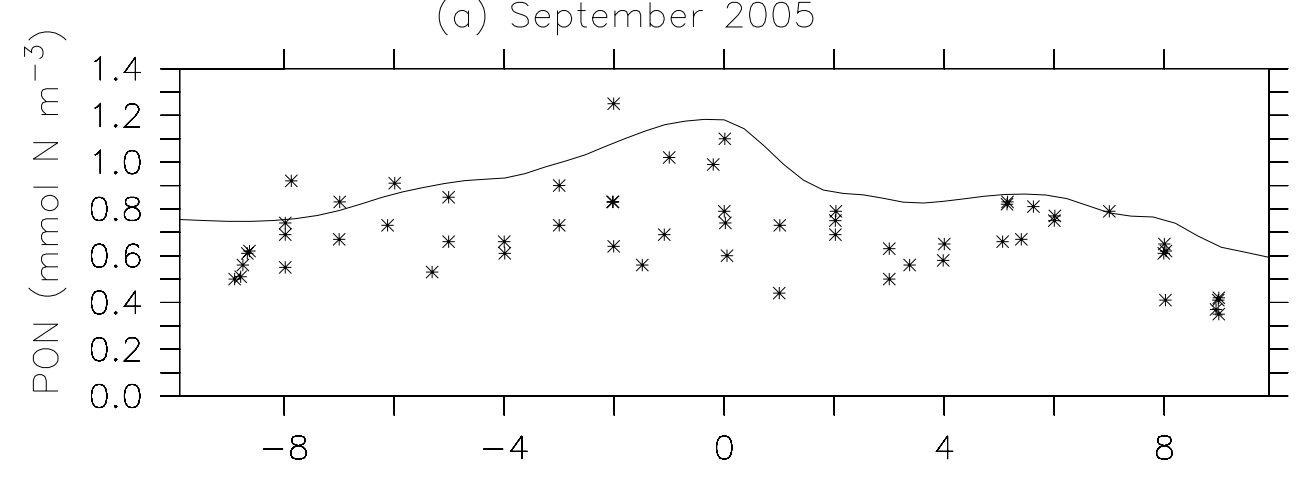

(b) January 2006

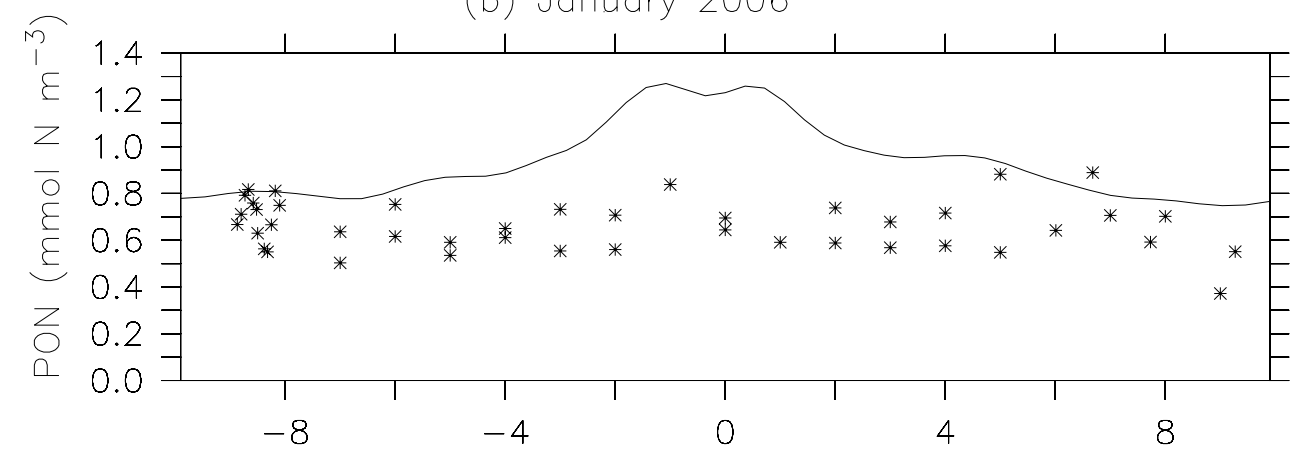

(c) September 2006

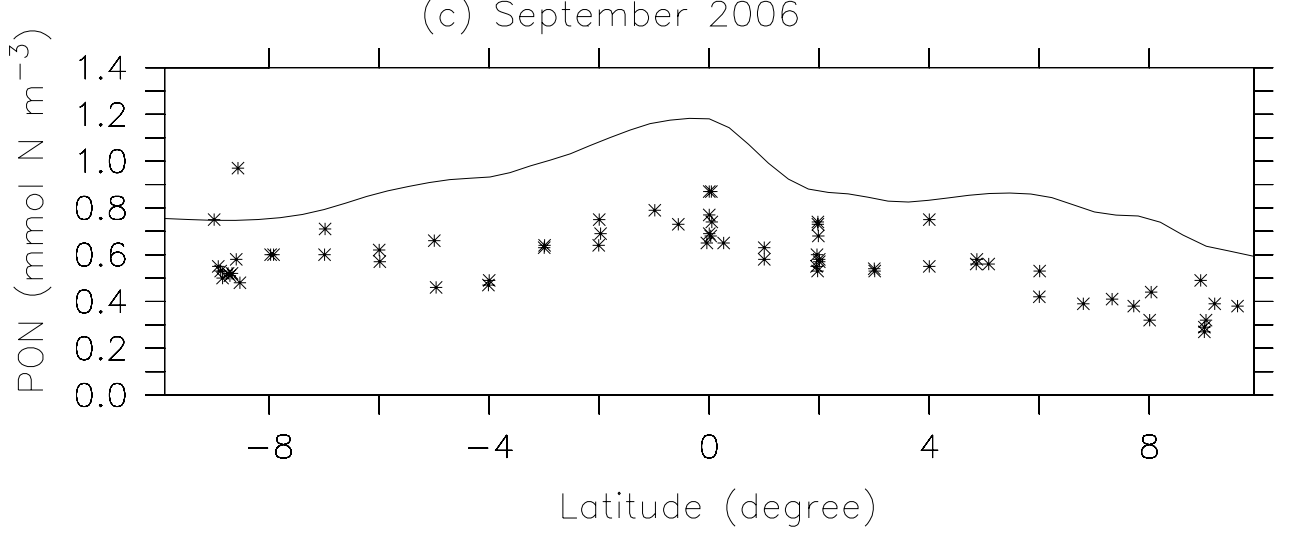

Fig. 4. Modeled (lines) versus measured (symbols) surface concentrations of PON $\left(140^{\circ} \mathrm{W}-125^{\circ} \mathrm{W}\right)$ in (a) September 2005), (b) January 2006, and (c) September 2006.

on the equator than off the equator along $110^{\circ} \mathrm{W}$, indicating enhanced biological activities, and thus PON accumulations in association with upwelling. While upwelling may bring PON-poor waters from the deep ocean into the surface (Pena et al., 1991), this study shows that biological accumulations exceed physical removals in the equatorial upwelling regions.

\subsection{Interannual variability}

The equatorial Pacific is known to undergo significant changes of physical and biogeochemical properties at interannual time-scales, which are associated with the El Niño/Southern Oscillation (ENSO). Our previous studies have shown significant interannual variations in phytoplankton and zooplankton biomass, primary productivity, new production, export production, net community production, and 

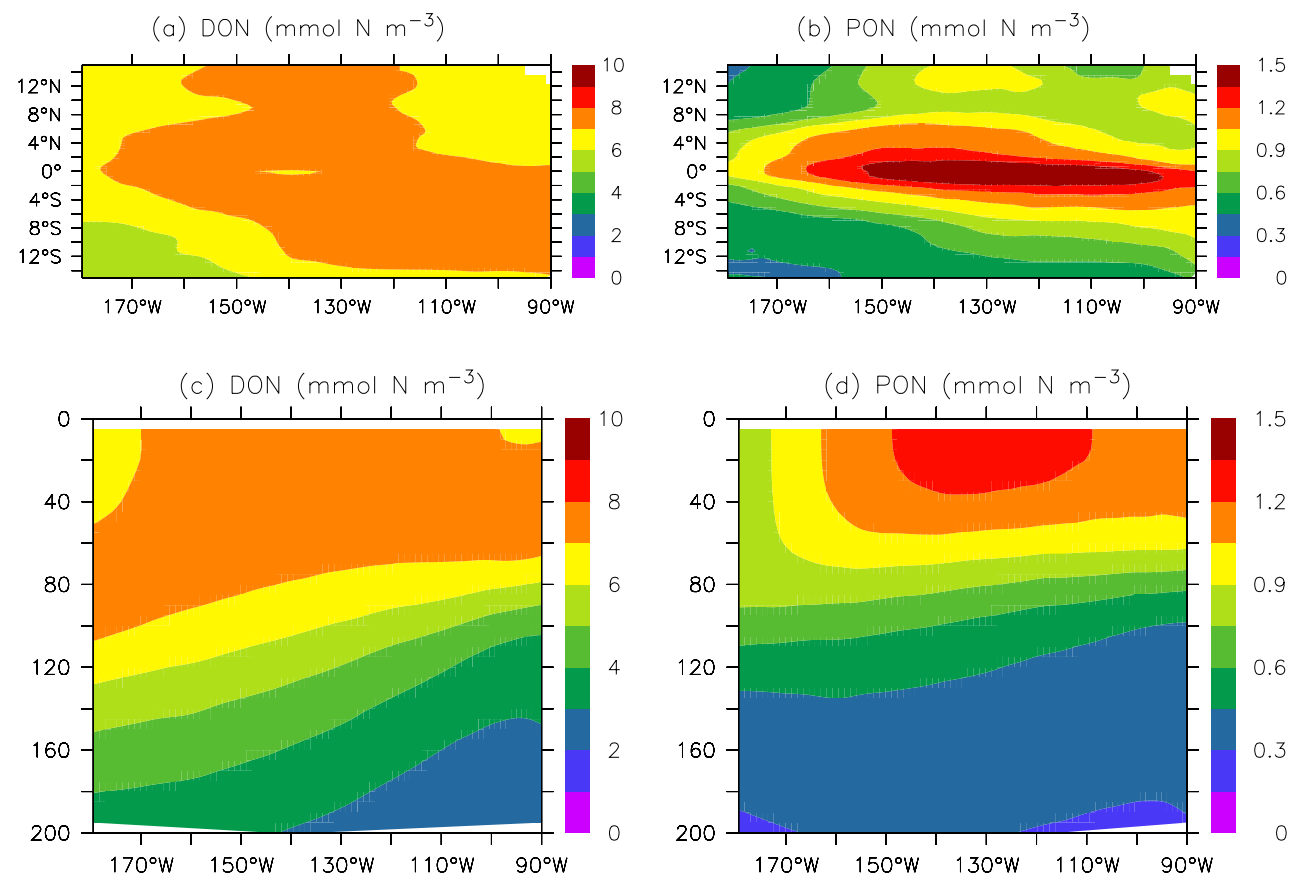

Fig. 5. Modeled climatology (1990-2007) of (a) mixed layer DON, (b) mixed layer PON, (c) DON profile $\left(5^{\circ} \mathrm{N}-5^{\circ} \mathrm{S}\right)$, and (d) PON profile $\left(5^{\circ} \mathrm{N}-5^{\circ} \mathrm{S}\right)$.
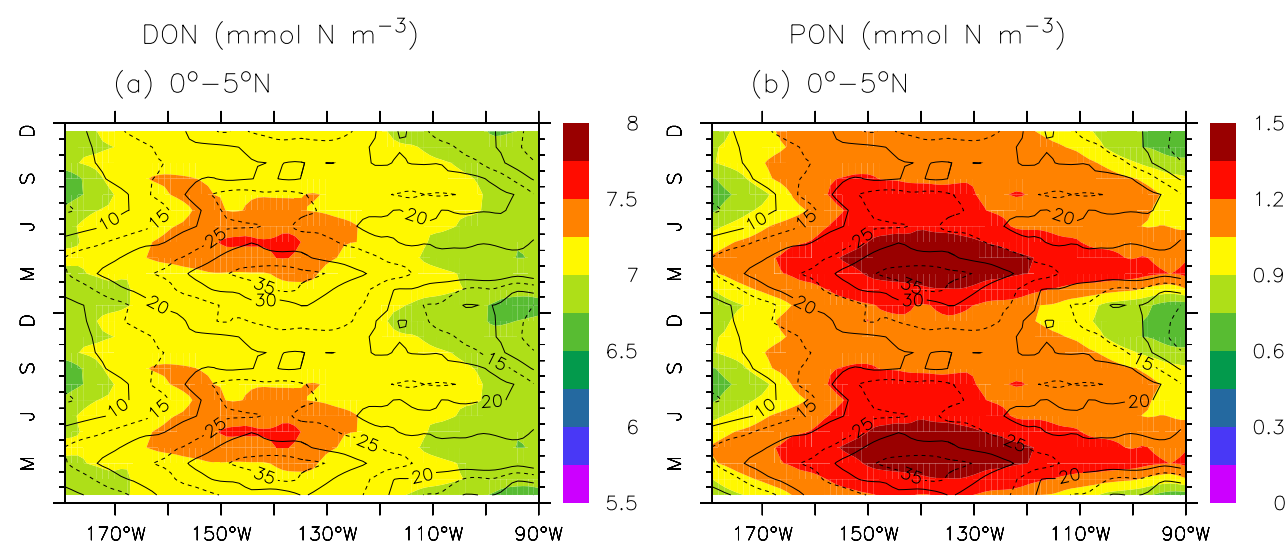

(c) $5^{\circ} \mathrm{S}-0^{\circ}$

(d) $5^{\circ} \mathrm{S}-0^{\circ}$
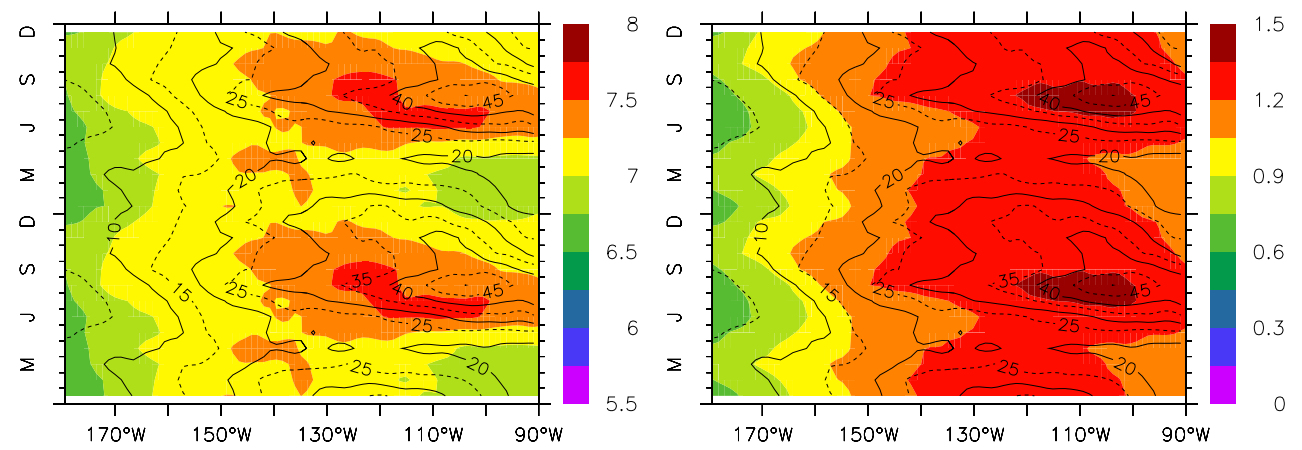

Fig. 6. Modeled seasonal climatology (over two years) of (a) DON $\left(5^{\circ} \mathrm{N}-0^{\circ}\right)$, (b) PON $\left(5^{\circ} \mathrm{N}-0^{\circ}\right)$, (c) $\mathrm{DON}\left(5^{\circ} \mathrm{S}-0^{\circ}\right)$, and (d) PON $\left(5^{\circ} \mathrm{S}-0^{\circ}\right)$ in the mixed layer. Superimposed black lines denote iron concentrations $\left(\mathrm{nmol} \mathrm{m}^{-3}\right)$ in the mixed layer. 
$150^{\circ} \mathrm{W}$

(a) March-May

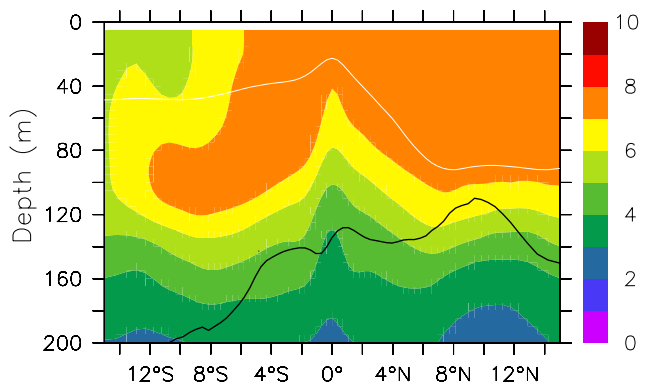

(c) September-November

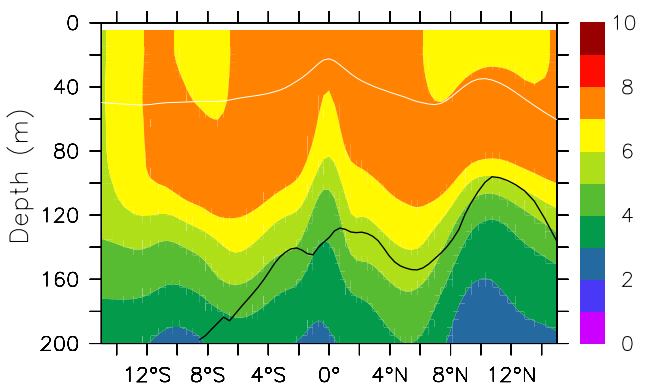

$110^{\circ} \mathrm{W}$

(b) March-May

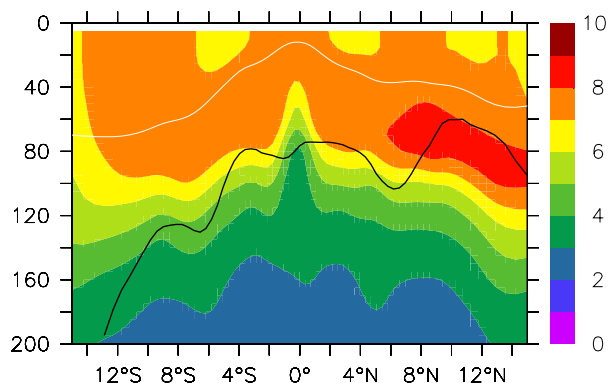

(d) September-November

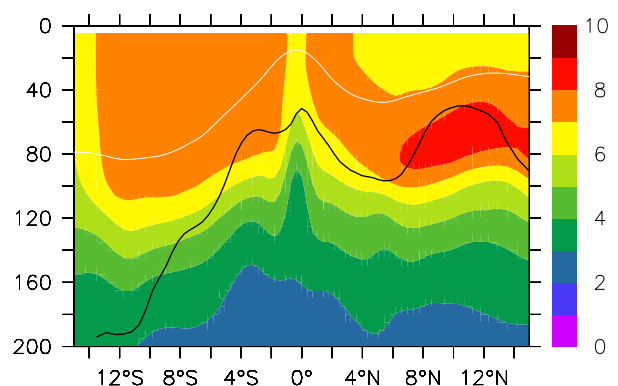

Fig. 7. Modeled DON profiles for the period of March-May along (a) $150^{\circ} \mathrm{W}$ and (b) $110^{\circ} \mathrm{W}$, and for September-November along (c) $150^{\circ} \mathrm{W}$ and (d) $110^{\circ} \mathrm{W}$. Superimposed white and black lines denote the MLD and the $20^{\circ} \mathrm{C}$ isotherm depth, respectively.

$150^{\circ} \mathrm{W}$

(a) March-May

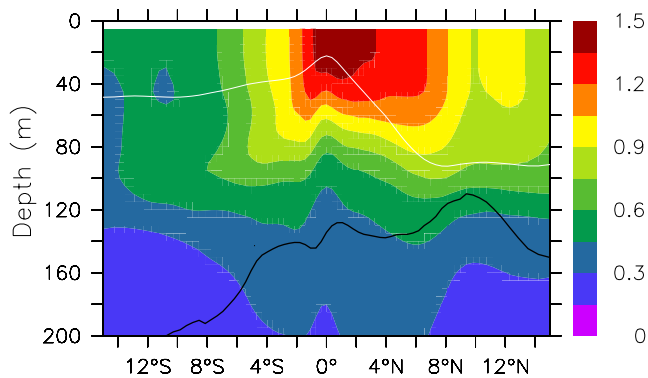

(c) September-November

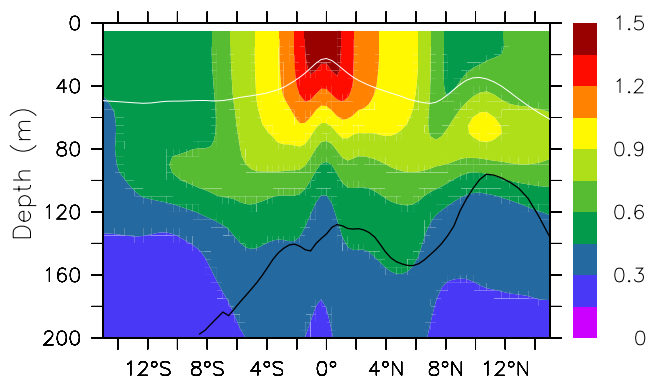

$110^{\circ} \mathrm{W}$

(b) March-May

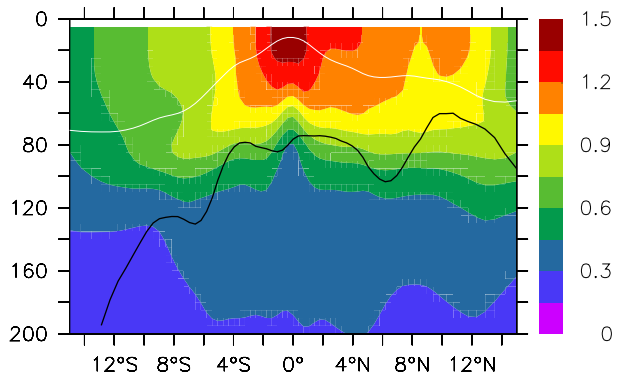

(d) September-November

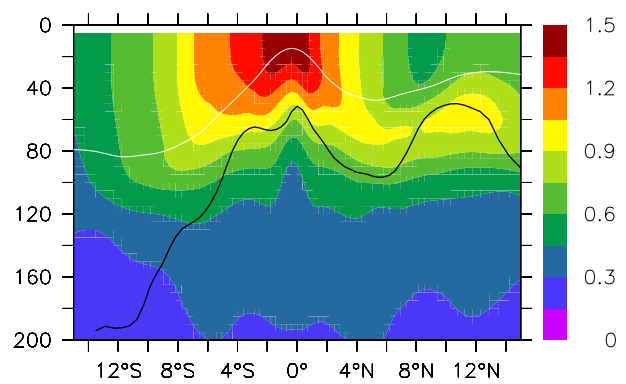

Fig. 8. Modeled PON profiles for the period of March-May along (a) $150^{\circ} \mathrm{W}$ and (b) $110^{\circ} \mathrm{W}$, and for September-November along (c) $150^{\circ} \mathrm{W}$ and (d) $110^{\circ} \mathrm{W}$. Superimposed white and black lines denote the MLD and the $20^{\circ} \mathrm{C}$ isotherm depth, respectively. 

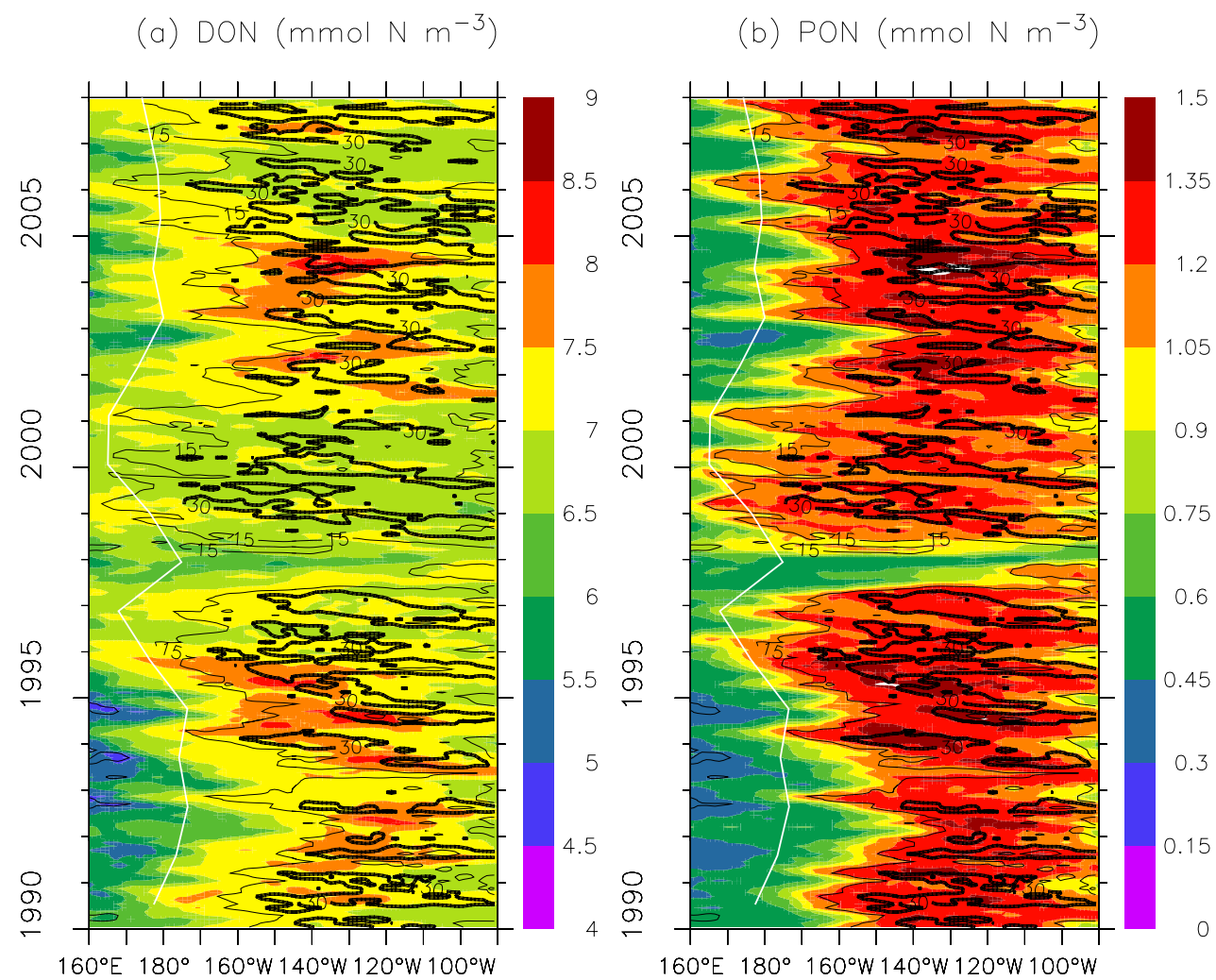

Fig. 9. Time-longitude contours of (a) DON (color contour) and iron concentrations (black lines), and (b) PON (color contour) and iron concentrations (black lines) averaged over the $5^{\circ} \mathrm{N}-5^{\circ} \mathrm{S}$ band. Superimposed white lines denote the longitude of $\mathrm{HNLC}$ front (173.2-10.75 SOI).

sea-air $\mathrm{CO}_{2}$ exchanges (Wang et al., 2005a, 2006a, b). Here, we present model simulations of DON and PON for the period of 1990-2007. Following our early studies, we employ an annual mean longitude of the HNLC front (Le Borgne et al., 2002) that is estimated from the Southern Oscillation Index (SOI): 173.2-10.75 SOI. The SOI values are annual means of the standardized Tahiti minus Darwin sealevel pressures obtained from the Climate Prediction Centre (http://www.cpc.ncep.noaa.gov).

Figure 9 presents the time series of iron, DON and PON concentrations in the mixed layer (averaged over $5^{\circ} \mathrm{N}-5^{\circ} \mathrm{S}$ ), together with the estimated HNLC front. Overall, there is a weak relationship between DON and iron concentration in the mixed layer. However, the mixed layer PON shows similar spatial and temporal variations to the mixed layer iron concentration. The model simulates a narrow range for the mixed layer DON $\left(6-8 \mathrm{mmol} \mathrm{m}^{-3}\right)$ in the HNLC region. Interestingly, modeled mixed layer DON concentrations are similar during fall, 1992 and fall, 1994, ruling out the possible contributions of interannual variability to the reported DON differences between along $150^{\circ} \mathrm{W}$ during November, 1994 (Raimbault et al., 1999) and along $125^{\circ} \mathrm{W}$ and $140^{\circ} \mathrm{W}$ during September-November 1992 (Libby and Wheeler, 1997).
The mixed layer PON concentration ranges from 0.5 to $1.5 \mathrm{mmol} \mathrm{m}^{-3}$ in the HNLC region, varying approximately by a factor of 3 . The temporal variations in the mixed layer DON and PON are smaller than most of the other biogeochemical parameters reported (varying by a factor of 3 to 10 ), including nutrients, chlorophyll, phytoplankton and zooplankton biomass, new production and export production (Chavez et al., 1999; McClain et al., 2002; Murtugudde et al., 1999; Wang et al., 2005a, 2006a).

Considering the differences in the DON and PON asymmetries between the eastern and central equatorial Pacific, we separate our analyses into four regions: the northcentral (NCP: $5^{\circ} \mathrm{N}-0^{\circ}, 150^{\circ} \mathrm{W}$ ), the south-central (SCP: $0^{\circ}-$ $\left.5^{\circ} \mathrm{S}, 150^{\circ} \mathrm{W}\right)$, the north-eastern (NEP: $\left.5^{\circ} \mathrm{N}-0^{\circ}, 110^{\circ} \mathrm{W}\right)$, and the south-eastern equatorial Pacific (SEP: $0^{\circ}-5^{\circ} \mathrm{S}$, $\left.110^{\circ} \mathrm{W}\right)$. Model simulations show considerable seasonalto-interannual variations in the mixed layer iron concentration (Figs. 6 and 9) and the ferricline (defined as the depth where iron concentration $=125 \mathrm{nmol} \mathrm{m}^{-3}$ ) in all the regions (Fig. 10). Apparently, the surface DON has little or weak relationships with the surface iron concentration in all four regions (Fig. 10). However, the subsurface DON varies with the ferricline: low DON concentration corresponding to a shallow ferricline. Statistical analyses indicate that the 

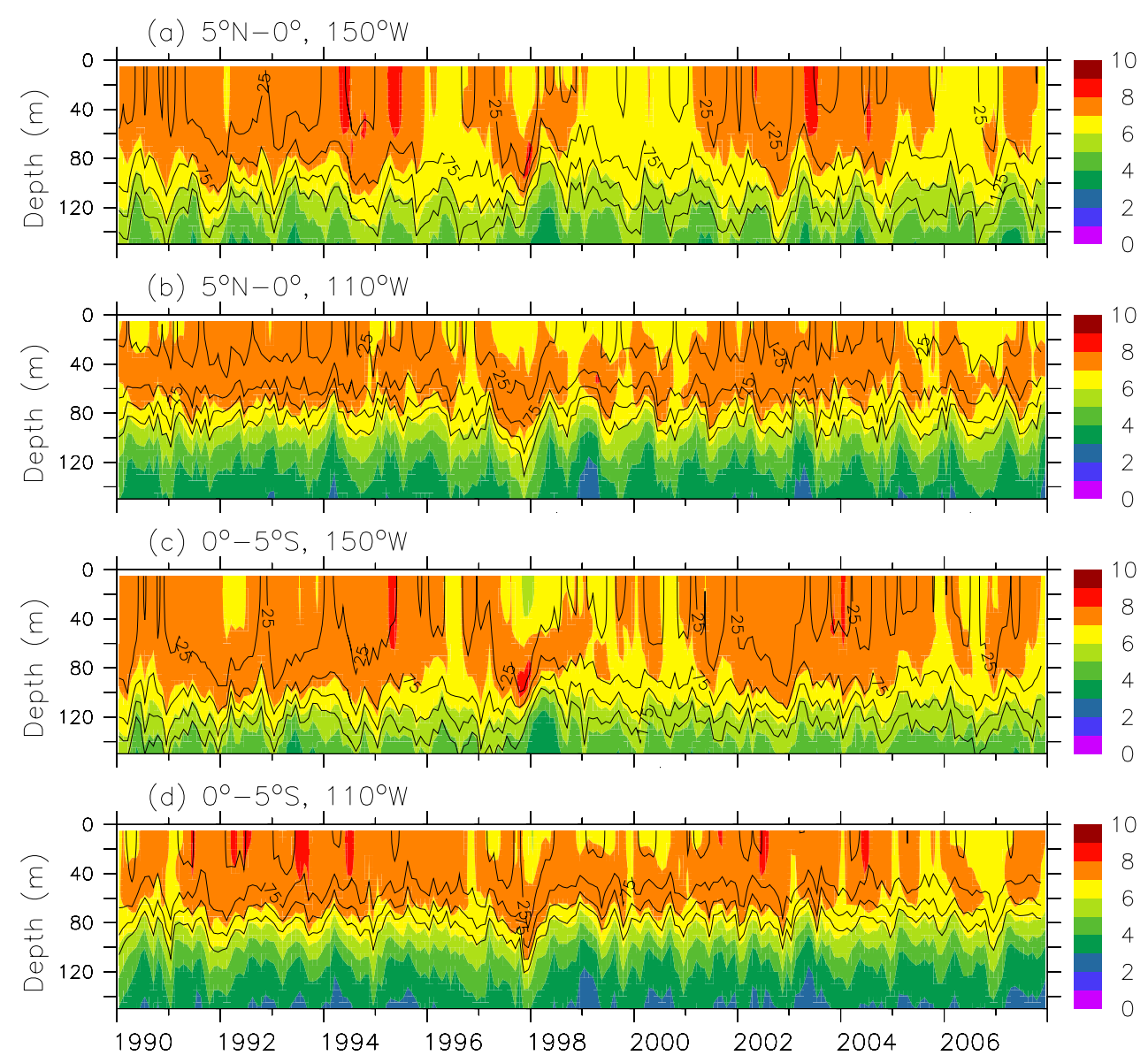

Fig. 10. Time-depth contours of DON averaged over (a) $5^{\circ} \mathrm{N}-0^{\circ}, 150^{\circ} \mathrm{W}$, (b) $5^{\circ} \mathrm{N}-0^{\circ}, 110^{\circ} \mathrm{W}$, (c) $0^{\circ}-5^{\circ} \mathrm{S}, 150^{\circ} \mathrm{W}$, and (d) $0^{\circ}-5^{\circ} \mathrm{S}$, $110^{\circ} \mathrm{W}$. Superimposed black lines denote iron concentrations of $25,75,125$ and $175 \mathrm{nmol} \mathrm{m}^{-3}$, respectively.

DON concentration at $120 \mathrm{~m}$ has highly significant $(r>0.77$, $\mathrm{p}<0.001$ ) correlations with the Z20, indicating strong implications of physical transport (i.e., upwelling of low-DON waters) for the subsurface DON variability in these regions.

Figure 11 shows depth-time distributions of $\mathrm{PON}$ and iron concentrations. The surface PON reveals moderate seasonal variations, except in the SCP. Unlike the surface DON, the temporal variations in the surface PON are consistent with those of the surface iron concentration. Overall, the surface $\mathrm{PON}$ shows considerable interannual variations with low concentrations $\left(<0.6 \mathrm{mmol} \mathrm{m}^{-3}\right)$ during the warm ENSO events (e.g., during the 1997/1998 El Niño). At $120 \mathrm{~m}$, the PON concentration has slightly weaker correlations $(r=$ 0.61-0.77) with the Z20 than the DON concentration ( $r=$ 0.77-0.83), suggesting more biological implications for the subsurface PON than for the subsurface DON.

\section{Discussion}

\subsection{Model-data and data-data comparisons}

There are generally good agreements in the magnitudes, meridional and vertical distributions between the modeled PON and observed PON. Interestingly, the simulated surface PON peak on the equator was not observed in boreal fall 1992 (Libby and Wheeler, 1997) or in boreal fall 1994 (Raimbault et al., 1999), but was observed in April 1988 (Pena et al., 1991; Pena et al., 1992) and in 2005-2006 (Fig. 4). The recent observations (at $3 \mathrm{~m}$ depth) show slightly higher PON concentrations along $140^{\circ} \mathrm{W}-125^{\circ} \mathrm{W}$ near the equator. These recent data also show some indication of diel cycle in the surface PON (Fig. 12a). For instance, high surface PON concentrations $\left(>1 \mathrm{mmol} \mathrm{m}^{-3}\right)$ are normally found before sunrise, which may reflect zooplankton migration to the top few meters during the night (Champalbert et al., 2003). Our model does not simulate zooplankton vertical migration. Here, we assume that zooplankton do not appear in near surface waters so modeled PON only consists 

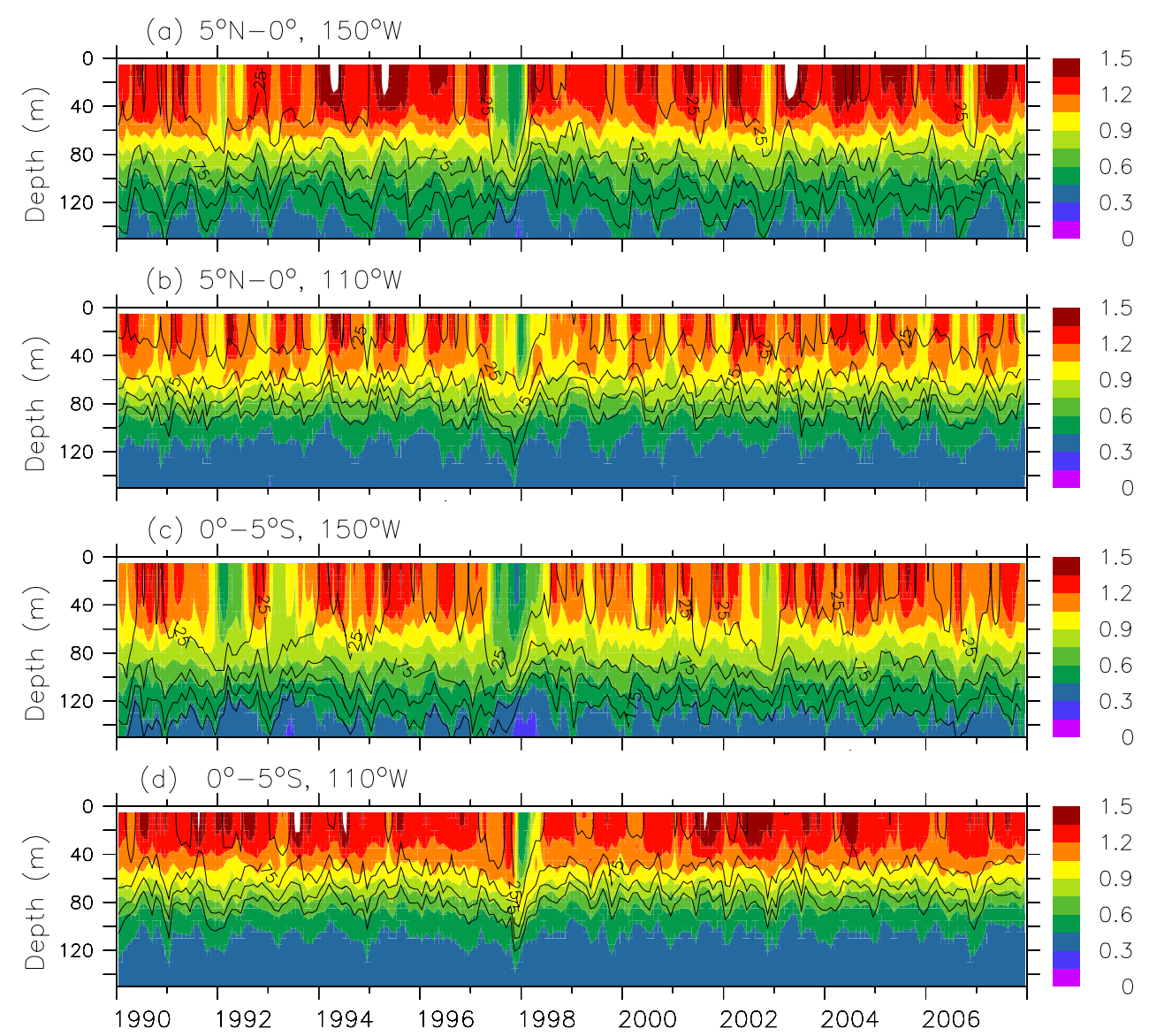

Fig. 11. Time-depth contours of PON averaged over (a) $5^{\circ} \mathrm{N}-0^{\circ}, 150^{\circ} \mathrm{W}$, (b) $5^{\circ} \mathrm{N}-0^{\circ}, 110^{\circ} \mathrm{W},(\mathbf{c}) 0^{\circ}-5^{\circ} \mathrm{S}, 150^{\circ} \mathrm{W}$, and $(\mathbf{d}) 0^{\circ}-5^{\circ} \mathrm{S}$, $110^{\circ} \mathrm{W}$. Superimposed black lines denote iron concentrations of $25,75,125$ and $175 \mathrm{nmol} \mathrm{m}^{-3}$, respectively.

of phytoplankton and detritus. This assumption leads to a better agreement between the modeled PON and measured PON (Fig. 12b). However, modeled PON concentrations are generally higher than observed ones. On the one hand, modeled PON pool may not represent observed PON pool in terms of composition. On the other hand, the PON concentrations measured on GF/F filters are considerably underestimated, particulrly using the $0.7 \mu \mathrm{m}$ filters (Libby and Wheeler, 1997). Apparently, more studies, both field measurements and modeling, are needed to better understand the PON variability.

The modeled surface DON concentrations are approximately $2 \mathrm{mmol} \mathrm{m}^{-3}$ lower than those from observations along $140^{\circ} \mathrm{W}$ and $125^{\circ} \mathrm{W}$ during September 1992 (Fig. 2). However, there is generally good agreement in the verticalmeridional distributions between modeled and measured DON along $150^{\circ} \mathrm{W}$ during November 1994 though the model overestimates the surface DON on the equator. There have been only two field studies of DON distribution in the equatorial Pacific which show approximately $2 \mathrm{mmol} \mathrm{m}^{-3}$ higher surface DON concentration along $125^{\circ} \mathrm{W}$ and $140^{\circ} \mathrm{W}$ during September-November 1992 (Libby and Wheeler,
1997) than along $150^{\circ} \mathrm{W}$ during November, 1994 (Raimbault et al., 1999). While there are no other in situ DON data in the equatorial Pacific, a field study shows that the surface TON concentrations are less than $6 \mathrm{mmol} \mathrm{m}^{-3}$ along $103^{\circ} \mathrm{W}-110^{\circ} \mathrm{W}$ in boreal spring 1994 (Hansell and Waterhouse, 1997), suggesting that the surface DON concentration might be close to those reported by Raimbault et al. (1999).

There have been reports of DON concentration in other parts of the ocean, showing a narrow range (4 to $7 \mathrm{mmol} \mathrm{m}^{-3}$ ) in a majority of the surface open ocean (Bronk, 2002; Aminot and Kerouel, 2004; Davis and Benner, 2005; Kahler and Koeve, 2001; Wong et al., 2002; Church et al., 2002). As Bronk (2002) summarized, the averaged DON concentration in the surface open ocean is $5.8 \mathrm{mmol} \mathrm{m}^{-3}$ with a standard deviation of $2 \mathrm{mmol} \mathrm{m}^{-3}$. There are a few studies showing relatively high DON concentrations (e.g., surface DON $>7 \mathrm{mmol} \mathrm{m}^{-3}$ ) (Bronk, 2002; Vidal et al., 1999). In the field, DON concentration is often obtained by subtracting TIN and PON from total nitrogen (TN) of unfiltered water samples (Libby and Wheeler, 1997; Raimbault et al., 1999), or by the difference between TN and TIN in filtered water samples (Aminot and Kerouel, 2004; Davis and 

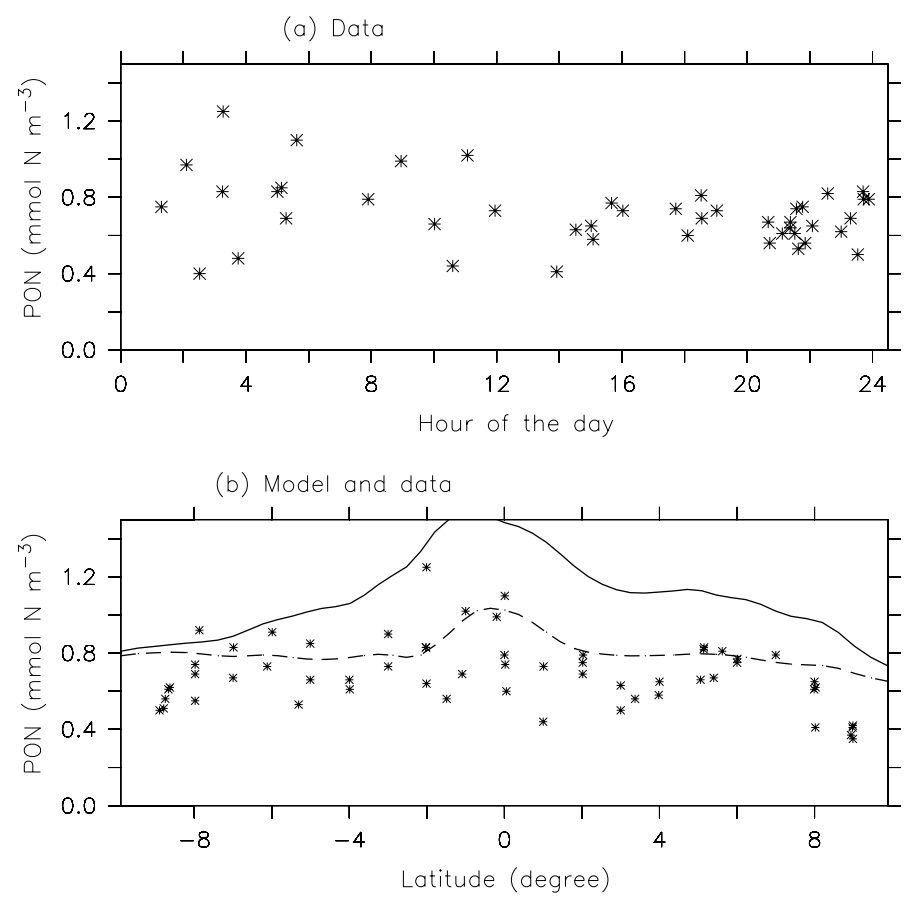

Fig. 12. Measured (symbols) and modeled (lines) surface PON concentrations along $140^{\circ} \mathrm{W}-125^{\circ} \mathrm{W}$ during September 2005 . (a) diel cycle and (b) meridional distributions. Solid line denotes total PON, dashed line PON without zooplankton.

Benner, 2005; Vidal et al., 1999). Therefore, in some published studies, the in situ DON pool may represent a small portion of other materials such as living matter and small detritus. Moreover, different approaches may yield inconsistent results because of the potential biases associated with the estimates of TON, PON, TN and TIN and uncertainties dealing with sample handling and analyzing. For instance, Vidal et al. (1999) reported relatively high DON concentrations $\left(5-11 \mathrm{mmol} \mathrm{m}^{-3}\right)$ with a subsurface maximum in the central equatorial Atlantic when they included ammonium in the DON pool. Clearly, more field studies, including development of improved techniques to measure DON and large scale observations, are needed for further model development and validation.

\subsection{Spatial and temporal variations}

The equatorial Pacific experiences significant seasonal to interannual physical forcings. Numerous studies have demonstrated that ENSO is the dominant mode regulating the spatial and temporal variations in physical and biogeochemical fields (Feely et al., 1999; Chavez et al., 1999; McPhaden et al., 1998; Wang et al., 2006a, b). As a result, interannual variations exceed seasonal variations in many biogeochemical parameters, including nutrients, phytoplankton and zooplankton biomass, primary productivity, new production, export production, and sea-air $\mathrm{CO}_{2}$ exchanges (Wang et al., 2006a, b).
Limited observations show considerable meridional, zonal and vertical variations in $\mathrm{PON}$ in the central and eastern equatorial Pacific (Libby and Wheeler, 1997; Pena et al., 1991, 1992; Raimbault et al., 1999). Our model simulations show significant spatial and temporal variations in PON in the central and eastern equatorial Pacific. Spatially, the highest PON concentrations are found along the equator in the surface waters of the eastern equatorial Pacific, which is similar to the spatial patterns of phytoplankton, zooplankton, primary production, and new production (Wang et al., 2006a). On average, the mixed layer PON ranges from $\sim 0.5 \mathrm{mmol} \mathrm{m}^{-3}$ during the extremely warm ENSO events to $>1 \mathrm{mmol} \mathrm{m}^{-3}$ during the cold ENSO phase. To quantify the temporal variability, we conducted One Way Analyses of Variance (ANOVA) (Storch and Zwiers, 2003) followed by the Least Significant Difference (LSD) test for both in situ PON and modeled PON. Table 1 shows that measured and modeled surface PON concentrations follow the same order: September 2005 > January 2006 > September 2006. The differences in both measured and modeled surface PON are significant (e.g., greater than the LSDs) among the three periods. At the interannual time scale, high surface PON coincides with high SOI. For instance, both SOI and surface PON concentrations are higher during September 2005 than during September 2006. The significant differences in surface PON between September 2005 and January 2006 reflect seasonal variability in the eastern equatorial Pacific (e.g., high PON during boreal fall). 
While there are relatively few DON measurements in the equatorial Pacific, there is evidence of the surface DON varying spatially by less than a factor of two. This modeling study and other regional in situ data (see summary in Bronk, 2002) suggest even smaller spatial variability. Our modeling study also shows much weaker seasonal to interannual variations in DON relative to PON (Table 1). More interestingly, the mixed layer DON increases from September 2005 to January 2006 while the mixed layer PON decreases. Our modeling results do not support the hypothesis that the reported differences in the surface DON concentration between Libby and Wheeler (1997) and Raimbault et al. (1999) result from the spatial or temporal variability.

\subsection{Relationships to other parameters}

Research has indicated that phytoplankton and zooplankton play a role in affecting DON and PON variations in the euphotic zone (Davis and Benner, 2005; Aminot and Kerouel, 2004; Bronk, 2002). Many studies have shown that phytoplankton and zooplankton biomass are affected by physical and biogeochemical conditions such as upwelling intensity, nutrient concentration and nutricline (Wang et al., 2005a, 2006a; Le Borgne et al., 1999, 2003), suggesting implications for the DON and PON variability.

Here, we examine the relationships of mixed layer DON and PON with the Z20, mixed layer iron concentration, ferricline, phytoplankton and zooplankton in four different regions. Statistical analyses indicate that the mixed layer DON has no relationship with Z20 or ferricline in three of four regions (Table 2). The positive correlation (0.15) of the mixed layer DON and Z20 in the SCP reflect the significance of upwelling of low-DON deep waters into the surface layer (Libby and Wheeler, 1997). In contrast, the mixed layer PON has significant negative correlations with Z20 and ferricline in three of four regions, indicating that strong upwelling (e.g., shallow Z20 and ferricline) results in high surface PON concentrations.

Overall, the mixed layer DON and PON have significant positive correlations with the mixed layer iron concentration (except north of the equator), phytoplankton and zooplankton. Interestingly, the relationships with phytoplankton and zooplankton are much stronger for PON than for DON. While both phytoplankton and zooplankton are key players for DON and PON abundance in the euphotic zone (Davis and Benner, 2005; Aminot and Kerouel, 2004; Bronk, 2002), upwelling of deep waters into the euphotic zone has larger impacts on DON than PON (Table 2). As a result, local DON accumulations due to phytoplankton release and zooplankton excretion are often offset by removal via physical transport, leading to low correlations between DON and biomass of phytoplankton and zooplankton. Nevertheless, the significant correlations of DON and PON with phytoplankton and zooplankton indicate that biological processes play an important role in controlling the distributions of organic nitrogen (Hansell and Waterhouse, 1997).

\section{Appendix A}

\section{Biogeochemical equations}

\section{Phytoplankton equations}

$\frac{\partial P_{S}}{\partial t}=\mu_{S} P_{S}-g_{P S}\left(1-e^{-\Lambda P_{S}}\right) Z_{S}-m_{S} P_{S}$

$\frac{\partial P_{L}}{\partial t}=\mu_{L} P_{L}-g_{P L 1}\left(1-e^{-\Lambda P_{L}}\right) Z_{L}$

$-g_{P L 2}\left(1-e^{-\Lambda P_{L}}\right) Z_{S}-m_{L} P_{L}$

\section{Zooplankton equations}

$$
\begin{aligned}
& \frac{\partial Z_{S}}{\partial t}=\left[\lambda\left(g_{P S}\left(1-e^{-\Lambda P_{S}}\right)+g_{P L 2}\left(1-e^{-\Lambda P_{L}}\right)\right)+\right. \\
& g_{D S}\left(1-e^{-\Lambda D_{S}}\right)+g_{D L 2}\left(1-e^{-\Lambda D_{L}}\right)- \\
& \left.\left(r_{S}+\delta_{S}\right)\right] Z_{S}-g_{Z S}\left(1-e^{-\Lambda Z_{S}}\right) Z_{L} \\
& \frac{\partial Z_{L}}{\partial t}=\left[\lambda\left(g_{P L 1}\left(1-e^{-\Lambda P_{L}}\right)+g_{Z S}\left(1-e^{-\Lambda Z_{S}}\right)\right)+\right. \\
& \left.g_{D L 1}\left(1-e^{-\Lambda D_{L}}\right)-\left(r_{L}+\delta_{L}\right)\right] Z_{L}
\end{aligned}
$$

\section{DON equation}

$$
\begin{aligned}
& \frac{\partial \mathrm{DON}}{\partial t}=\left(m_{S} P_{S}+m_{L} P_{L}+\left(r_{S} Z_{S}+r_{L} Z_{L}\right) \chi\right) \gamma+ \\
& \left(c_{D S} D_{S}+c_{D L} D_{L}\right) \zeta-c_{\mathrm{DON}} \mathrm{DON}
\end{aligned}
$$

\section{Detritus equations}

$$
\begin{aligned}
& \frac{\partial D_{S}}{\partial t}=\left(m_{S} P_{S}+m_{L} P_{L}+\left(r_{S} Z_{S}+r_{L} Z_{L}\right) \chi\right)(1-\gamma) \\
& -g_{D S}\left(1-e^{-\Lambda D_{S}}\right) Z_{S}-\left(c_{D S}+w_{D S} h^{-1}\right) D_{S} \\
& \frac{\partial D_{L}}{\partial t}=(1-\lambda)\left[\left(g_{P S}\left(1-e^{-\Lambda P_{S}}\right)+g_{P L 2}\left(1-e^{-\Lambda P_{L}}\right)\right) Z_{S}\right] . \\
& \left.+\left(g_{P L 1}\left(1-e^{-\Lambda P_{L}}\right)+g_{Z S}\left(1-e^{-\Lambda Z_{S}}\right)\right) Z_{L}\right]+\delta_{S} Z_{S}+\delta_{L} Z_{L} \\
& -\left(c_{D L}+w_{D L} h^{-1}\right) D_{L}-g_{D L 2}\left(1-e^{-\Lambda D_{L}}\right) Z_{S}-g_{D L 1}\left(1-e^{-\Lambda D_{L}}\right) Z_{L}
\end{aligned}
$$




\section{Nutrient equations}

$\frac{\partial \mathrm{NO}_{3}}{\partial t}=-\mu_{S} P_{S} \frac{N_{S_{-} U P}}{N_{S_{-} U P}+A_{U P}}-$

$\mu_{L} P_{L} \frac{N_{L_{-} U P}}{N_{L_{-} U P}+A_{U P}}+\varphi \mathrm{NH}_{4}$

$\frac{\partial \mathrm{NH}_{4}}{\partial t}=-\mu_{S} P_{S} \frac{A_{\mathrm{up}}}{N_{S_{-} U P}+A_{\mathrm{UP}}}$

$-\mu_{L} P_{L} \frac{A_{u p}}{N_{L_{-} \mathrm{UP}}+A_{\mathrm{UP}}}+\left(r_{S} Z_{S}+r_{L} Z_{L}\right)(1-\chi)$

$+c_{\mathrm{DON}} \mathrm{DON}+\left(c_{D S} D_{S}+c_{D L} D_{L}\right)(1-\zeta)-\varphi \mathrm{NH}_{4}$

$\frac{\partial \mathrm{Fe}}{\partial t}=-\left(\mu_{S} P_{S} R_{S}+\mu_{L} P_{L} R_{L}-s_{\mathrm{Fe}} D_{L} \mathrm{Fe}\right)$

$+R_{S}\left[\left(r_{S} Z_{S}+r_{L} Z_{L}\right)(1-\chi)+c_{\mathrm{DON}} \mathrm{DON}+\right.$

$\left.c_{D S} D_{S}+c_{D L} D_{L}(1-\zeta)\right]$

\section{Other equations}

\section{Phytoplankton growth rate}

$\mu_{S}=\mu_{\mathrm{S} 0} e^{k_{T} T} f(I) \psi_{S}(\mathrm{~N}, \mathrm{Fe})$

$\mu_{L}=\mu_{\mathrm{L} 0} e^{k_{T} T} f(I) \psi_{L}(\mathrm{~N}, \mathrm{Fe})$

\section{Nutrient limitation}

$\psi_{S}(\mathrm{~N}, \mathrm{Fe})=\min \left(\frac{\mathrm{NO}_{3}+\mathrm{NH}_{4}}{K_{S_{-} N}+\mathrm{NO}_{3}+\mathrm{NH}_{4}}, \frac{\mathrm{Fe}}{K_{S_{-} \mathrm{Fe}}+\mathrm{Fe}}\right)$

$\psi_{L}(\mathrm{~N}, \mathrm{Fe})=\min \left(\frac{\mathrm{NO}_{3}+\mathrm{NH}_{4}}{K_{L_{-} N}+\mathrm{NO}_{3}+\mathrm{NH}_{4}}, \frac{\mathrm{Fe}}{K_{L-\mathrm{Fe}}+\mathrm{Fe}}\right)$

\section{Light limitation}

$f(I)=1-e^{-\frac{\alpha I}{\eta P_{\max }^{c}}}$

\section{Light attenuation}

$I(z)=I_{0} \exp ^{-k_{A} Z}$

(A10)

$$
k_{A}=k_{W}+k_{C} \mathrm{Chl}+k_{D}\left(D_{S}+D_{L}\right)
$$

\section{Carbon to chlorophyll ratio $(\eta)$}

$\mathrm{Chl}=\left(\frac{P_{S}}{\eta_{S}}+\frac{P_{L}}{\eta_{L}}\right) R_{C: N}$

$\eta_{S}=\eta_{\mathrm{S} 0}-\left(\eta_{\mathrm{S} 0}-\eta_{\mathrm{MIN}}\right) \frac{\ln I_{0}-\ln I}{4.605}$

$\eta_{L}=\eta_{\mathrm{L} 0}-\left(\eta_{\mathrm{L} 0}-\eta_{\mathrm{MIN}}\right) \frac{\ln I_{0}-\ln I}{4.605}$

$\eta_{\mathrm{S} 0}=\eta_{\mathrm{S} \_\mathrm{MAX}}-k_{\mathrm{PS}} \mu_{S}^{*}$

$\eta_{\mathrm{L} 0}=\eta_{\mathrm{L} \_\mathrm{MAX}}-k_{\mathrm{PL}} \mu_{L}^{*}$

$\mu_{S}^{*}=\mu_{\mathrm{S} 0} e^{k_{T} T} \min \left(\frac{\mathrm{NO}_{3}}{K_{S_{-} N}+\mathrm{NO}_{3}}, \frac{\mathrm{Fe}}{K_{\mathrm{S} \_\mathrm{Fe}}+\mathrm{Fe}}\right)$

$\mu_{L}^{*}=\mu_{\mathrm{L} 0} e^{k_{T} T} \min \left(\frac{\mathrm{NO}_{3}}{K_{L_{-} N}+\mathrm{NO}_{3}}, \frac{\mathrm{Fe}}{K_{\mathrm{L}_{-} \mathrm{Fe}}+\mathrm{Fe}}\right)$

\section{Nitrogen uptake}

$N_{\mathrm{S} \_\mathrm{UP}}=\frac{\mathrm{NO}_{3}}{K_{\mathrm{S}_{-} \mathrm{NO}_{3}}+\mathrm{NO}_{3}}\left(1-\frac{\mathrm{NH}_{4}}{K_{\mathrm{NH}_{4}}+\mathrm{NH}_{4}}\right)$

$N_{L_{-} U P}=\frac{N O_{3}}{K_{L_{-} N O_{3}}+N O_{3}}\left(1-\frac{N H_{4}}{K_{N H_{4}}+N H_{4}}\right)$

$A_{\mathrm{UP}}=\frac{\mathrm{NH}_{4}}{K_{\mathrm{NH}_{4}}+\mathrm{NH}_{4}}$

DON remineralization

$c_{\mathrm{DON}}=c_{\mathrm{DON} 0} e^{k_{B}(T-26)}$

\section{Detritus decomposition}

$c_{\mathrm{DS}}=c_{\mathrm{DS} 0} e^{k_{B}(T-26)}$

$c_{\mathrm{DL}}=c_{\mathrm{DL} 0} e^{k_{B}(T-26)}$ 


\section{Appendix B}

\section{Model biological parameters}

\begin{tabular}{|c|c|c|c|}
\hline Parameter & Symbol & Unit & Value \\
\hline \multirow{2}{*}{ Maximum growth rate at $0^{\circ} \mathrm{C}$} & $\mu_{\mathrm{S} 0}$ & $d^{-1}$ & 0.58 \\
\hline & $\mu_{\mathrm{L} 0}$ & $d^{-1}$ & 1.16 \\
\hline Temp. dependent coefficient for $\mu$ & $k_{\mathrm{T}}$ & ${ }^{\circ} \mathrm{C}^{-1}$ & 0.06 \\
\hline \multirow[t]{2}{*}{ Half saturation constant for $\mathrm{N}$ limitation } & $K_{\mathrm{S} \_\mathrm{N}}$ & $\mathrm{mmol} \mathrm{m}^{-3}$ & 0.2 \\
\hline & $K_{\mathrm{L} \_\mathrm{N}}$ & $\mathrm{mmol} \mathrm{m}^{-3}$ & 0.6 \\
\hline \multirow[t]{2}{*}{ Half saturation constant for iron limitation } & $K_{\mathrm{S} \_\mathrm{Fe}}$ & $\mathrm{nmol} \mathrm{m}{ }^{-3}$ & 14 \\
\hline & $K_{\mathrm{L} \_} \mathrm{Fe}$ & $\mathrm{nmol} \mathrm{m}^{-3}$ & 150 \\
\hline \multirow[t]{2}{*}{ Half saturation constant for nitrate uptake } & $K_{\mathrm{S} \_\mathrm{NO} 3}$ & $\mathrm{mmol} \mathrm{m}^{-3}$ & 0.3 \\
\hline & $K_{\mathrm{L} \_\mathrm{NO} 3}$ & $\mathrm{mmol} \mathrm{m}^{-3}$ & 0.9 \\
\hline Half saturation constant for ammonium uptake & $K_{\mathrm{NH} 4}$ & $\mathrm{mmol} \mathrm{m}^{-3}$ & 0.05 \\
\hline \multirow[t]{2}{*}{ Phytoplankton mortality rate } & $m_{\mathrm{S}}$ & $\mathrm{d}^{-1}$ & 0.17 \\
\hline & $m_{\mathrm{L}}$ & $d^{-1}$ & 0.31 \\
\hline \multirow[t]{2}{*}{ Zooplankton excretion rate } & $r_{\mathrm{S}}$ & $\mathrm{d}^{-1}$ & 0.5 \\
\hline & $r_{\mathrm{L}}$ & $d^{-1}$ & 0.4 \\
\hline \multirow{2}{*}{ Zooplankton mortality rate } & $\delta_{\mathrm{S}}$ & $d^{-1}$ & 0.12 \\
\hline & $\delta_{\mathrm{L}}$ & $d^{-1}$ & 0.09 \\
\hline \multirow[t]{7}{*}{ Maximum grazing rate } & $g_{\mathrm{PS}}$ & $d^{-1}$ & 2.9 \\
\hline & $g_{\text {PL1 }}$ & $d^{-1}$ & 1.2 \\
\hline & $g_{\mathrm{ZS}}$ & $d^{-1}$ & 1.7 \\
\hline & $g_{\text {PL2 }}$ & $d^{-1}$ & 0.9 \\
\hline & $g_{\mathrm{DS}}$ & $d^{-1}$ & 1.0 \\
\hline & $g_{\text {DL1 }}$ & $d^{-1}$ & 1.5 \\
\hline & $g_{\text {DL2 }}$ & $\mathrm{d}^{-1}$ & 1.0 \\
\hline Ivlev coefficient & $\Lambda$ & $\left.(\mathrm{mmol} \mathrm{N} \mathrm{m})^{-3}\right)^{-1}$ & 0.5 \\
\hline Zooplankton assimilation coefficient & $\lambda$ & $\%$ & 75 \\
\hline Excretion coefficient & $\chi$ & $\%$ & 55 \\
\hline \multirow[t]{2}{*}{ Dissolution coefficient } & $\gamma$ & $\%$ & 90 \\
\hline & $\zeta$ & $\%$ & 90 \\
\hline $\mathrm{C}: \mathrm{N}$ ratio & $R_{\mathrm{C}: \mathrm{N}}$ & $\mathrm{mol} \mathrm{mol}^{-1}$ & 6.625 \\
\hline \multirow[t]{2}{*}{ Fe:N ratio } & $R_{\mathrm{S}}$ & $\mu \mathrm{mol} \mathrm{mol}^{-1}$ & 25 \\
\hline & $R_{\mathrm{L}}$ & $\mu \mathrm{mol} \mathrm{mol}^{-1}$ & 50 \\
\hline Initial slope of the $P-I$ curve & $\alpha$ & $\mathrm{mgC} \mathrm{mg} \mathrm{chl}{ }^{-1} \mathrm{~h}^{-1}\left(\mu \mathrm{molEm}^{-2} \mathrm{~s}^{-1}\right)^{-1}$ & 0.02 \\
\hline Maximum carbon specific growth rate & $P_{\mathrm{MAX}}^{C}$ & $\mathrm{~h}^{-1}$ & 0.036 \\
\hline \multirow[t]{2}{*}{ Minimum C:Chl ratio } & $\eta_{\text {S_MIN }}$ & $\mathrm{g}: \mathrm{g}$ & 30 \\
\hline & $\eta_{\mathrm{L} \_\mathrm{MIN}}$ & $\mathrm{g}: \mathrm{g}$ & 15 \\
\hline \multirow[t]{2}{*}{ Maximum C:Chl ratio } & $\eta_{\text {S_MAX }}$ & $\mathrm{g}: \mathrm{g}$ & 200 \\
\hline & $\eta_{\text {L_MAX }}$ & $\mathrm{g}: \mathrm{g}$ & 120 \\
\hline \multirow[t]{2}{*}{ Photoacclimation coefficient } & $k_{\mathrm{PS}}$ & $(\mathrm{g}: \mathrm{g}) \mathrm{d}$ & 95 \\
\hline & $k_{\mathrm{PL}}$ & $(\mathrm{g}: \mathrm{g}) \mathrm{d}$ & 70 \\
\hline Light attenuation constant for water & $k_{\mathrm{W}}$ & $\mathrm{m}^{-1}$ & 0.028 \\
\hline Light attenuation constant for chlorophyll & $k_{\mathrm{C}}$ & $\mathrm{m}^{-1}\left(\mathrm{mg} \mathrm{chl} \mathrm{m}^{-3}\right)^{-1}$ & 0.058 \\
\hline Light attenuation constant for detritus & $k_{\mathrm{D}}$ & $\left.\mathrm{m}^{-1}(\mathrm{mmol} \mathrm{N} \mathrm{m})^{-3}\right)^{-1}$ & 0.008 \\
\hline \multirow[t]{2}{*}{ Sinking velocity } & $w_{\mathrm{DS}}$ & $\mathrm{md}^{-1}$ & 1 \\
\hline & $w_{\mathrm{DL}}$ & $\mathrm{md}^{-1}$ & 3.5 \\
\hline Remineralization rate at $26^{\circ} \mathrm{C}(0-100 \mathrm{~m})$ & $c_{\text {DONO }}$ & $\mathrm{d}^{-1}$ & 0.0025 \\
\hline$(100-300 \mathrm{~m})$ & $c_{\text {DONO }}$ & $\mathrm{d}^{-1}$ & $0.0008-0.0025$ \\
\hline$(>300 \mathrm{~m})$ & $c_{\text {DONO }}$ & $d^{-1}$ & 0.0008 \\
\hline \multirow[t]{2}{*}{ Decomposition rate } & $c_{\text {DSO }}$ & $d^{-1}$ & 0.01 \\
\hline & $c_{\text {DL0 }}$ & $\mathrm{d}^{-1}$ & 0.01 \\
\hline Temp. dependent coefficient for $c$ & $k_{B}$ & ${ }^{\circ} \mathrm{C}^{-1}$ & 0.03 \\
\hline Iron scavenge coefficient & $\mathrm{s}_{\mathrm{Fe}}$ & $\mathrm{d}^{-1}\left(\mathrm{nmol} \mathrm{Fe} \mathrm{m}^{-3}\right)^{-1}$ & 0.00001 \\
\hline Nitrification rate (when $\mathrm{I}<5 \mu \mathrm{molE} \mathrm{m}^{-2} \mathrm{~s}^{-1}$ ) & $\phi$ & $\mathrm{d}^{-1}$ & 0.04 \\
\hline
\end{tabular}


Acknowledgements. This work is supported by grants from the National Aeronautics and Space Administration. We thank Julie Arrington for the in situ PON measurements.

Edited by: C. Slomp

\section{References}

Aminot, A. and Kerouel, R.: Dissolved organic carbon, nitrogen and phosphorus in the N-E Atlantic and the N-W Mediterranean with particular reference to non-refractory fractions and degradation, Deep-Sea Res. I-Ocean. Res., 51, 1975-1999, 2004.

Archer, D., Aiken, J., Balch, W., Barber, D., Dunne, J., Flament, P., Gardner, W., Garside, C., Goyet, C., Johnson, E., Kirchman, D., McPhaden, M., Newton, J., Peltzer, E., Welling, L., White, J., and Yoder, J.: A meeting place of great ocean currents: shipboard observations of a convergent front at 2 degrees $\mathrm{N}$ in the Pacific, Deep-Sea Res. II, 44, 1827-1849, 1997.

Behrenfeld, M. J. and Boss, E.: Beam attenuation and chlorophyll concentration as alternative optical indices of phytoplankton biomass, J. Mar. Res., 64, 431-451, 2006.

Behrenfeld, M. J., Worthington, K., Sherrell, R. M., Chavez, F. P., Strutton, P., McPhaden, M., and Shea, D. M.: Controls on tropical Pacific Ocean productivity revealed through nutrient stress diagnostics, Nature, 442, 1025-1028, 2006.

Bronk, D. A.: Dynamics of DON, in: Biogeochemistry of Marine Dissolved Organic Matter, edited by: Hansell, D. A., and Carlson, C. A., Academic Press, San Diego, USA, 153-247, 2002.

Chai, F., Dugdale, R. C., Peng, T. H., Wilkerson, F. P., and Barber, R. T.: One-dimensional ecosystem model of the equatorial Pacific upwelling system. Part I: model development and silicon and nitrogen cycle, Deep-Sea Res. II, 49, 2713-2745, 2002.

Champalbert, G., Neveux, J., Gaudy, R., and Le Borgne, R.: Diel variations of copepod feeding and grazing impact in the highnutrient, low-chlorophyll zone of the equatorial Pacific Ocean (0 degrees; 3 degrees S, 180 degrees), J. Geophys. Res.-Oceans, 108, 8145, doi:8110.1029/2001JC000810, 2003.

Chavez, F. P., Strutton, P. G., Friederich, C. E., Feely, R. A., Feldman, G. C., Foley, D. C., and McPhaden, M. J.: Biological and chemical response of the equatorial Pacific Ocean to the 1997-98 El Nino, Science, 286, 2126-2131, 1999.

Chen, D., Rothstein, L. M., and Busalacchi, A. J.: A hybrid vertical mixing scheme and its application to tropical ocean models, J. Phys. Ocean., 24, 2156-2179, 1994.

Christian, J. R., Verschell, M. A., Murtugudde, R., Busalacchi, A. J., and McClain, C. R.: Biogeochemical modelling of the tropical Pacific Ocean. I: Seasonal and interannual variability, Deep-Sea Res. II, 49, 509-543, 2002.

Church, M. J., Ducklow, H. W., and Karl, D. M.: Multiyear increases in dissolved organic matter inventories at station ALOHA in the North Pacific Subtropical Gyre, Limnol. Oceanogr., 47, 110, 2002.

Coale, K. H., Fitzwater, S. E., Gordon, R. M., Johnson, K. S., and Barber, R. T.: Control of community growth and export production by upwelled iron in the equatorial Pacific Ocean, Nature, 379, 621-624, 1996.

Cronin, M. F. and Kessler, W. S.: Seasonal and interannual modulation of mixed layer variability at 0 degrees, 110 degrees $\mathrm{W}$, Deep-Sea Res. Part I-Ocean. Res., 49, 1-17, 2002.
Davis, J. and Benner, R.: Seasonal trends in the abundance, composition and bioavailability of particulate and dissolved organic matter in the Chukchi/Beaufort Seas and western Canada Basin, Deep-Sea Res. II, 52, 3396-3410, 2005.

Dugdale, R. C. and Wilkerson, F. P.: Silicate regulation of new production in the equatorial Pacific upwelling, Nature, 391, 270273, 1998.

Dugdale, R. C., Wischmeyer, A. G., Wilkerson, F. P., Barber, R. T., Chai, F., Jiang, M. S., and Peng, T. H.: Meridional asymmetry of source nutrients to the equatorial Pacific upwelling ecosystem and its potential impact on ocean-atmosphere $\mathrm{CO}_{2}$ flux; a data and modeling approach, Deep-Sea Res. II, 49, 2513-2531, 2002.

Eppley, R. W., Chavez, F. P., and Barber, R. T.: Standing stocks of particulate carbon and nitrogen in the Equatorial Pacific at 150Degrees-W, J. Geophys. Res.-Ocean., 97, 655-661, 1992.

Feely, R. A., Wanninkhof, R., Goyet, C., Archer, D. E., and Takahashi, T.: Variability of $\mathrm{CO}_{2}$ distributions and sea-air fluxes in the central and eastern equatorial pacific during the 1991-1994 El Niño, Deep-Sea Res. II, 44, 1851-1867, 1997.

Feely, R. A., Wanninkhof, R., Takahashi, T., and Tans, P.: Influence of El Nino on the equatorial Pacific contribution to atmospheric $\mathrm{CO}_{2}$ accumulation, Nature, 398, 597-601, 1999.

Feely, R. A., Boutin, J., Cosca, C. E., Dandonneau, Y., Etcheto, J., Inoue, H. Y., Ishii, M., Quere, C. L., Mackey, D. J., and McPhaden, M.: Seasonal and interannual variability of $\mathrm{CO}_{2}$ in the equatorial Pacific, Deep Sea Res. II, 49, 2443-2469, 2002.

Feely, R. A., Takahashi, T., Wanninkhof, R., McPhaden, M. J., Cosca, C. E., Sutherland, S. C., and Carr, M. E.: Decadal variability of the air-sea $\mathrm{CO} 2$ fluxes in the equatorial Pacific Ocean, J. Geophys. Res.-Ocean., 111, C08S90, doi:10.1029/2005JC003129, 2006.

Gardner, W. D., Mishonov, A., and Richardson, M. J.: Global POC concentrations from in-situ and satellite data, Deep-Sea Res. II, 53, 718-740, 2006.

Gent, P. R. and Cane, M. A.: A reduced gravity, primitive equation model of the upper Equatorial Ocean, J. Comput. Phys., 81, 444480, 1989.

Hansell, D. A. and Waterhouse, T. Y.: Controls on the distributions of organic carbon and nitrogen in the eastern Pacific Ocean, Deep-Sea Res. I-Oceanogr. Res., 44, 843-857, 1997.

Jiang, M. S. and Chai, F.: Physical and biological controls on the latitudinal asymmetry of surface nutrients and $\mathrm{pCO}_{2}$ in the central and eastern equatorial Pacific, J. Geophys. Res.-Ocean., 110, C06007, doi:06010.01029/02004JC002715, 2005.

Kahler, P. and Koeve, W.: Marine dissolved organic matter: can its C:N ratio explain carbon overconsumption?, Deep-Sea Res. I-Oceanogr. Res., 48, 49-62, 2001.

Kalnay, E., Kanamitsu, M., Kistler, R., Collins, W., Deaven, D., Gandin, L., Iredell, M., Saha, S., White, G., Woollen, J., Zhu, Y., Chelliah, M., Ebisuzaki, W., Higgins, W., Janowiak, J., Mo, K. C., Ropelewski, C., Wang, J., Leetmaa, A., Reynolds, R., Jenne, R., and Joseph, D.: The NCEP/NCAR 40-year reanalysis project, Bull. Am. Meteorol. Soc., 77, 437-471, 1996.

Kug, J. S., Kang, I. S., and An, S. I.: Symmetric and antisymmetric mass exchanges between the equatorial and off-equatorial $\mathrm{Pa}$ cific associated with ENSO, J. Geophys. Res.-Ocean., 108, 3284, doi:3210.1029/2002JC001671, 2003. 
Landry, M. R., Barber, R. T., Bidigare, R. R., Chai, F., Coale, K. H., Dam, H. G., Lewis, M. R., Lindley, S. T., McCarthy, J. J., Roman, M. R., Stoecker, D. K., Verity, P. G., and White, J. R.: Iron and grazing constraints on primary production in the central equatorial Pacific - an EqPac synthesis, Limnol. Oceanogr., 42, 405-418, 1997.

Landry, M. R. and Kirchman, D. L.: Microbial community structure and variability in the tropical Pacific, Deep Sea Res. II, 49, 2669 2693, 2002.

Le Borgne, R., Rodier, M., Le Bouteiller, A., and Murray, J. W.: Zonal variability of plankton and particle export flux in the equatorial Pacific upwelling between 165 degrees $\mathrm{E}$ and 150 degrees W, Oceanol. Acta, 22, 57-66, 1999.

Le Borgne, R., Barber, R. T., Delcroix, T., Inoue, H. Y., Mackey, D. J., and Rodier, M.: Pacific warm pool and divergence: temporal and zonal variations on the equator and their effects on the biological pump, Deep Sea Res. II, 49, 2471-2512, 2002.

Le Borgne, R., Champalbert, G., and Gaudy, R.: Mesozooplankton biomass and composition in the equatorial $\mathrm{Pa}-$ cific along 180 degrees, J. Geophys. Res., 108, 8143, dio:8110.1029/2001JC000745, 2003.

Le Borgne, R. and Landry, M. R.: EBENE: A JGOFS investigation of plankton variability and trophic interactions in the equatorial Pacific (180 degrees), J. Geophys. Res., 108, 8136, doi:8110.1029/2001JC001252, 2003.

Libby, P. S. and Wheeler, P. A.: Particulate and dissolved organic nitrogen in the central and eastern equatorial Pacific, Deep-Sea Res. I, 44, 345-361, 1997.

Martin, J. H., Coale, K. H., Johnson, K. S., Fitzwater, S. E., Gordon, R. M., Tanner, S. J., Hunter, C. N., Elrod, V. A., Barber, R. T., Lindley, S., Watson, A. J., and Van Scoy, K.: Testing the iron hypothesis in ecosystems of the equatorial Pacific Ocean, Nature, 371, 123-129, 1994.

McClain, C. R., Christian, J. R., Signorini, S. R., Lewis, M. R., Asanuma, I., Turk, D., and Dupouy-Douchement, C.: Satellite ocean-color observations of the tropical Pacific Ocean, Deep Sea Res. II, 49, 2533-2560, 2002.

McPhaden, M. J., Busalacchi, A. J., Cheney, R., Donguy, J. R., Gage, K. S., Halpern, D., Ji, M., Julian, P., Meyers, G., Mitchum, G. T., Niiler, P. P., Picaut, J., Reynolds, R. W., Smith, N., and Takeuchi, K.: The tropical ocean global atmosphere observing system: A decade of progress, J. Geophys. Res.-Ocean., 103, 14 169-14 240, 1998.

Murray, J. W., Johnson, E., and Garside, C.: A U.S. JGOFS process study in the equatorial Pacific (EqPac): Introduction, Deep Sea Res. II, 42, 275-293, 1995.
Murtugudde, R., Seager, R., and Busalacchi, A.: Simulation of the tropical oceans with an ocean GCM coupled to an atmospheric mixed-layer model, J. Climate, 9, 1795-1815, 1996.

Murtugudde, R. G., Signorini, S. R., Christian, J. R., Busalacchi, A. J., McClain, C. R., and Picaut, J.: Ocean color variability of the tropical Indo-Pacific basin observed by SeaWiFS during 19971998, J. Geophys. Res., 104, 18 351-18 366, 1999.

Pena, M. A., Lewis, M. R., and Harrison, W. G.: Particulate organic-matter and chlorophyll in the surface layer of the equatorial Pacific Ocean along $135^{\circ}$ W, Mar. Ecol.-Prog. Ser., 72, 179 $188,1991$.

Pena, M. A., Harrison, W. G., and Lewis, M. R.: New production in the central equatorial Pacific, Mar. Ecol.-Prog. Ser., 80, 265-274, 1992.

Raimbault, P., Slawyk, G., Boudjellal, B., Coatanoan, C., Conan, P., Coste, B., Garcia, N., Moutin, T., and Pujo-Pay, M.: Carbon and nitrogen uptake and export in the equatorial Pacific at 150 degrees W: Evidence of an efficient regenerated production cycle, J. Geophys. Res., 104, 3341-3356, 1999.

Storch, H. v. and Zwiers, F. W.: Statistical analysis in climate research, Cambridge Press Cambridge, UK, 484 pp., 2003.

Vidal, M., Duarte, C. M., and Agusti, S.: Dissolved organic nitrogen and phosphorus pools and fluxes in the central Atlantic Ocean, Limnol. Oceanogr., 44, 106-115, 1999.

Wang, X. J., Christian, J., Murtugudde, R., and Busalacchi, A.: Ecosystem dynamics and export production in the central and eastern equatorial Pacific: a modeling study of impact of ENSO, Geophys. Res. Lett., 32, L02608, doi:02610.01029/02004GL021538, 2005a.

Wang, X. J., Murtugudde, R., Busalacchi, A., and Le Borgne, R.: De-coupling of net community production and new production in the equatorial Pacific Ocean: a model study, Geophys. Res. Lett., 32, L21601, doi:21610.21029/22005GL024100, 2005 b.

Wang, X. J., Christian, J. R., Murtugudde, R., and Busalacchi, A. J.: Spatial and temporal variability in new production in the equatorial Pacific during 1980-2003: Physical and biogeochemical controls, Deep-Sea Res. II, 53, 677-697, 2006a.

Wang, X. J., Christian, J. R., Murtugudde, R., and Busalacchi, A. J.: Spatial and temporal variability of the surface water $\mathrm{pCO}_{2}$ and air-sea $\mathrm{CO}_{2}$ flux in the equatorial Pacific during 1980-2003: a basin-scale carbon model, J. Geophys. Res., 111 C07S04, doi:10.1029/2005JC002972, 2006b.

Wong, C. S., Yu, Z., Waser, N. A. D., Whitney, F. A., and Johnson, W. K.: Seasonal changes in the distribution of dissolved organic nitrogen in coastal and open-ocean waters in the North East Pacific: sources and sinks, Deep-Sea Res. II, 49, 5759-5773, 2002. 